\title{
Union Leadership and Member Attitudes: A Multi-Level Analysis
}

\author{
Tove Helland Hammer, Mahmut Bayazit, David. L. Wazeter ${ }^{1}$
}

Analyses of union leadership roles show that union presidents should have both a withinunion focus and an external focus. The authors combined multi-level survey data from 3,871 union members in 248 local teachers' unions with archival and field staff data to examine relationships between leadership and members' perceptions of union instrumentality and justice, union commitment, and participation. The results showed significant union-level effects on members' beliefs about, and attitudes toward, their unions, attributable to the presidents' internal and external leadership, wage outcomes, and union characteristics. Relationships between internally focused leadership and members' loyalty and willingness to work for the union were partially mediated by perceptions of union instrumentality and justice. These perceptions fully mediated the relationship between externally focused leadership and union loyalty.

Meta-analyses and other summaries of studies on union members' commitment to, and participation in, their locals show that union instrumentality, pro-union attitudes, job satisfaction, and organizational commitment combine, either directly or indirectly, to cause union commitment (e.g., Bamberger, Kluger, \& Suchard, 1999; Barling, Fullagar, \& Kelloway, 1992), which, in turn, contributes to union participation (see Fullagar, Gallagher, Clark, \& Carroll, 2004).

The immediate antecedents of union commitment and participation are thus either attitudes toward, or perceptions of, the union and the employer. Both are institutions, not actors. It is assumed, of course, that there are actors both inside and outside the union and the employer who create the conditions that lead to union commitment and participation, but there has been very little research done on what the actors do and how their actions shape union involvement. In this study, we examine the relationships between union leadership, in the form of local union presidents, and the antecedents of union commitment and participation. We focus on those attitudes and perceptions that lead to union involvement, in particular, on union members' beliefs about union instrumentality and justice, because it will allow us to test some of the assumptions behind the hypotheses that link leadership and member involvement. We believe that the effects of leadership are more likely to be felt, and therefore observed, on the perceptions and beliefs that lead to member commitment and participation, because it is the role, or duty, of union leaders to secure the conditions on which members' perceptions and

\footnotetext{
${ }^{1}$ Tove Helland Hammer, Department of Organizational Behavior, School of Industrial and Labor Relations, Cornell University; Mahmut Bayazit, Sabanci University, Istanbul, Turkey; David L. Wazeter, Pennsylvania State Education Association, Harrisburg, PA. We thank Richard W. Hurd, David B. Lipsky, and William J. Sonnenstuhl for helpful assistance with a draft of the article. Correspondence concerning this article should be addressed to Tove Helland Hammer, 146 Ives Hall East, School of Industrial and Labor Relations, Cornell University, Ithaca, NY 14853-3901. Email: thh2@cornell.edu
} 
beliefs are based. There is closer proximity between what a union leader does and the consequences of union membership for the rank-and-file than there is between leadership and members' commitment and participation. As part of this study, we also test hypotheses about the mediating effects of instrumentality beliefs and justice perceptions on the relationships between leader behaviors and member commitment and participation.

We consider union leadership to be a group-, or organization-, level variable, in the sense that the union leader is a part of the social context to which people belong, or in which they work, and as such is a shared experience for rank-and-file union members. The union leader can be viewed as a property, or characteristic, of the union. If there are leadership effects on union commitment and participation, we expect that part of the variance in the members' beliefs and attitudes can be attributed to the union to which they belong. We therefore have in this study a large sample of local unions, each with a separate leader, the union president, to allow us to model effects on both the individual and the union level.

There is another important reason for testing hypotheses about leadership effects with a multiple-union research design. A union leader's ability to serve the interests of rank-and-file members depends in part on external factors, such as the economy or the employer. To isolate the effects of leadership on those dimensions of union effectiveness that involve the followers, one must control for organizational and environmental characteristics that influence members' perceptions, attitudes, and behaviors. These are in part union specific, but they should include union density, labor market conditions, and employer munificence (Hammer \& Avgar, 2005). One could argue that environmental factors are exogenous to the relationship between the union and its members and that their influence is therefore already captured by the union's ability to protect its members from the vagaries of labor markets and employers' financial health. However, it is just as likely that these factors do not operate solely through union instrumentality but have a direct influence on commitment levels and participation. Their effects are an empirical question. This means, in turn, that we need research samples of multiple unions or union locals that vary in external characteristics, both to be able to isolate the union-level variance in members' attitudes and behaviors that can be attributed to the union's leadership as well as to ensure that leadership effects are not biased upward.

There is theoretically and empirically coherent research in industrial relations and labor economics on how unions, or union membership, influence employee attitudes toward the job and the employer (e.g., Bryson, Cappellari, \& Lucifora, 2004; Freeman \& Medoff, 1984; Lincoln \& Booth, 1993). In contrast, the few studies that have included leadership in models of union commitment and participation are an idiosyncratic collection of theoretical approaches, case studies, and scattered findings about shop stewards, not union presidents. The shop steward is the union official with whom rank-and-file members are likely to have most daily contact, but the steward's role, although quite broad in theory (Nash, 1983), is limited to servicing members, primarily by handling grievances, solving personal disputes between individual members and the employer, and acting as an information conduit between union officers and the membership (e.g., Catlett \& Brown, 1990; Chang, 2005). It is the president of the local union who is responsible for ensuring that the union reaches its organizational goals. Because the president is responsible for all aspects of union effectiveness, in both the internal life of the union and in the union's relationships with important external actors, he or she is more likely to determine the conditions that encourage members' attachment to, and appreciation of, their 
union, such as the nature and strength of the union contract, the quality of labor-management relations, or the union's success as a protector of workplace rights. ${ }^{2}$

The importance of the presidents' role was illustrated in the early studies of the transition in U.S. industrial relations from a rule-based "job-control unionism" system with industry-wide pattern bargaining toward a model that includes formal and informal structures of worker participation, decentralized bargaining with local union autonomy, and flexible firmor plant-specific job classifications (Kochan, Katz, \& McKersie, 1986). More recent studies of local unions demonstrate how union officers, primarily presidents, represent the memberships' interests through their engagement in workplace governance and firm strategy (Eaton, Rubinstein, \& Kochan, 2008; Rubinstein, 2001). Research on teachers' unions, conducted in the wake of the education reform movement that started in the mid-1980s, also shows how local union presidents negotiated collaborative partnerships with school boards and superintendents and worked to expand school-based decision making for teachers (Kerchner \& Koppick, 1993; Kerchner \& Mitchell, 1988; Urbanski, 1990).

Our study is important for three reasons. First, there is hardly any empirical research available on top-level leadership in local unions. ${ }^{3}$ Yet, it is well known that employment relations in the unionized workplace depend on the quality of both management and union leadership (e.g., Frost, 2000; Katz \& Darbishire, 2000; Kochan et al., 1986). Second, we examine how union leaders can contribute to the conditions that result in member commitment and participation. We do so to allow a more differentiated picture of the processes through which union leaders influence member reactions than the picture made possible in prior studies. Third, this is, to our knowledge, the first study of union effects on member attitudes that controls for organizational characteristics based on a large sample of unions.

\section{Modeling Union Leadership}

Because studies of local union leadership have focused almost exclusively on shop stewards, we review these briefly. Early case studies described the stewards' roles and power inside the union hierarchy and on the shop floor (e.g., Batstone, Boraston, \& Frenkel, 1977; Marchington \& Armstrong, 1983; Sayles \& Strauss, 1967). Research on the psychological processes through which stewards might influence rank-and-file union members' attitudes and behaviors followed two different paths. One set of studies tested hypotheses about the effects of stewards' transformational leadership characteristics on member commitment and participation (Fullagar, Clark, Gallagher, \& Gordon, 1994; Fullagar, McCoy, \& Shull, 1992; Kelloway \& Barling, 1993). The second set examined the stewards' service orientation, defined as being accessible and available to the members, listening to their concerns, keeping them informed about union activity, and encouraging expression of opinions (Metochi, 2002; Nicholson, Ursell, \& Blyton, 1980; Thacker, Fields, \& Barklay, 1990).

\footnotetext{
${ }^{2}$ Other union officers, such as a secretary-treasurer, vice-president, or committee chairs, may share the president's leadership responsibilities. In some local unions, particularly in the construction and building trades, a business agent is the central union officer responsible for contract negotiations and the union's relationship with the employer.

${ }^{3}$ An exception is an in-depth case study of union governance in the International Typographical Union (Lipset, Trow, \& Coleman, 1956), which, although focused on national-level leaders, included analyses of leadership in union locals.
} 
In addition, Skarlicki and Latham $(1996,1997)$ examined the effects of training shop stewards to use principles of procedural and interactional justice on the basis of the assumption that union members would be more willing to participate in the union when they saw the leaders as sincere and fair.

\section{The Role of the Union President}

The question then becomes: What can union leaders do to influence members' beliefs about instrumentality and justice, as well as their attitudes toward the union? We sought the answer not in traditional leadership theories but in an analysis of the union president's role in building and maintaining effective local unions.

The traditional role of a local union president includes preparing for negotiations, actual bargaining, policing the union contract, and ensuring that the grievance process works. In addition, the role involves managing the internal life of the union, which includes tasks shared with, or delegated to, shop stewards, such as building up the local by keeping members informed about the local's present activities and future plans on all fronts; encouraging members to attend meetings and vote in union elections; soliciting information from members about their concerns; resolving internal conflicts and building consensus; recruiting new members; and training, coaching, and educating members for union roles. In short, the local union president works to make the union an active and beneficial presence in each member's mind.

Servicing the membership has been, and continues to be, the dominant model of local union leadership in the U.S. The servicing model is anchored in the union's role as protector of people's workplace interests and rights. It was long assumed that the more effective unions were at solving members' problems for them, the stronger the union would be as an institution (Grabelsky \& Hurd, 1994). However, an unanticipated consequence of having unionleaders and staff focus on service was complacent union members who did not participate actively in the union's struggle to ensure their rights. New strategies developed at the national union level to revitalize local unions and recruit new members with an organizing model, however, have not diminished the importance of service to the rank-and-file (for descriptions and research on the organizing model, see Bronfenbrenner, Friedman, Hurd, Oswald , \& Seeber, 1998; Fletcher \& Hurd, 1998; Hurd, 1998; for evaluations of the organizing model, see Hurd, 2004). ${ }^{4}$ This does

\footnotetext{
${ }^{4}$ Declines in union density throughout the 1970 s and 1980 s led the AFL-CIO to develop new strategies at both the national and local level to increase membership. The organizing model was supposed to increase union growth in two ways, by allocating resources to recruitment (external organizing) and by energizing and activating existing union members at the local level to enable them to solve their own workplace problems (internal organizing). It was assumed that empowering the rank-and-file would rekindle the grassroots activism and commitment that characterized the union movement's earlier days, which, in turn, would make unions more visible and attractive to the unorganized, and also free up union staff and leadership to focus on external organizing. A variant on the internal organizing model is the Mutual Aid Logic, in which members are trained to help one another with personal and substance abuse problems (Bacharach, Bamberger, \& Sonnenstuhl, 2001). The organizing model requires that union officers create structures and procedures, and train and supervise union staff, for recruitment, as well as train rank-and-file members to service themselves and fellow members. Evaluations of the organizing model have shown modest gains in overall membership growth and, at best, temporary increases in local union activism. By and large, union members have been unwilling to trade being serviced for the personal demands of empowerment, and union staff and leaders have been overwhelmed by new tasks, skills, and time demands. Efforts at internal organizing have been largely abandoned, although the external organizing model is operative at the local level in several national unions. There are still efforts to rekindle local union militancy by following the Bronfenbrenner model of using the time during contract negotiations to mobilize the rank-and-file, but this is rare in teachers' unions (R. W. Hurd, personal communication, April 4, 2008).
} 
not mean that local union leaders can safely ignore efforts to involve the members in the union's business on a daily basis or to mobilize them around special tasks or events, such as contract negotiations and job actions. The union's ability to enhance and protect member interests depends also on the solidarity of an actively engaged membership, which is why it is important for unions to find ways to increase member commitment and participation.

We identify three different, but interrelated, components of the president's withinunion focused leadership. These are (a) keeping members informed and educated about the union, the contract, and their workplace rights; (b) enforcing the contract and resolving conflicts and problems for the individual member; and (c) consulting with and including members in the administration of the local.

Informing and educating members involves giving members information about the local as an institution, about its present policies and future plans, and about its relationship with the state and national (or international) union; it involves counseling members about their rights under the union contract and how the union works to assist its members; and it involves teaching them about the duties and obligations of union membership. Contract enforcement and conflict resolution includes monitoring the employer's adherence to the contract terms throughout and beyond the hours of work, helping members file grievances and attending grievance hearings, and solving conflicts between individual members and the employer, or among members. Consulting and including members means involving the members in decision making, delegating union tasks to the members, and soliciting opinions about contract proposals and other important matters.

Although these are conceptually different sets of behaviors, they are interrelated in the sense that they are likely to occur together in interactions between president and members. They should therefore have the same effect on, or relationship with, members' beliefs about union instrumentality and justice. It is also possible that members will not compartmentalize their perceptions of the president but instead see him or her as more or less actively engaged working for them and for the local as an institution. This is especially true when there is physical distance between the union president who resides in the union office and rank-and-file members who are located in different workplaces.

The management of external relations, which involves a variety of administrative and coalition building activities aimed at increasing the union's chances to improve wages, benefits, and working conditions for its members, is also an important part of the president's role (Katz \& Darbishire, 2000; Kochan et al., 1986). Externally focused activities include preparing for negotiations by gathering economic and contract data from inside and outside the local, developing negotiating teams and plans for impasse and job actions, building external political networks for future support, collaborating with the employer on integrative issues, working with the state- and national-level union staff, and making long-range plans about membership drives, bargaining goals, or the union's response to future problems. Again, these activities can be grouped into conceptually distinct categories, such as preparing for negotiations or working with external union staff on long-range planning for the local, but the common denominator is the external focus aimed at making the local more effective in reaching its goals. It is therefore not obvious that they would have different effects on members' beliefs about the utility of the union. One could, perhaps, argue that one set of activities would have a stronger effect on union effectiveness than would another set, but we have no prior basis for such a hypothesis. 
The externally focused behaviors work together to produce results, and their possible differential effects on local union strength is an empirical question.

A number of these functions, such as preparing for negotiations, actual bargaining, or external coalition building, cannot be observed easily by rank-and-file union members because the activities may occur infrequently and, when they do, are likely to happen outside the members' direct experience with the president. If union presidents are effective managers of external relations, however, members should experience the results in the form of bargaining outcomes and in the nature of the labor-management relationship.

To assess both the internal and external leadership of the union presidents, we need information from different observers who can capture the leaders' activities in the different domains. Those familiar with how the union president carries out his or her responsibilities away from the membership may also know how well the president functions within the local, in part because they may observe the results of the internally focused leadership, but it is the rank-and-file union members who are the immediate observers of how the president acts vis-avis them. We therefore examine local union leadership from two vantage points: the union members' perceptions from within the union and the assessment of the more externally focused leadership from the state and national union's field staff. The outcome variables in this study are the members' beliefs and attitudes, however, so the hypotheses concern those only.

\section{Hypotheses}

Most models of union commitment and participation include union instrumentality, by which is usually meant the union's ability to deliver on wages, benefits, and other conditions of employment, and pro-union attitudes, usually defined as positive beliefs about unions as institutions. Scholars disagree about their relative importance, however. Some argue for the primacy of the union's instrumental role over its ideological role, especially in the U.S. (e.g., Kochan et al., 1986); others consider both as predictors that can follow different paths (e.g., Bamberger et al., 1999; Barling et al., 1992). Missing in the debate about the relative importance of ideology and values is the recognition that unions differ with respect to history, ties to political parties, goals, the occupational identity of their members, national cultural values, and legal systems. Some unions have a strong ideological commitment to trade unionism as a political or social movement; others have less. ${ }^{5}$

We suggest that the utility of union membership goes beyond economic gains and employment rights to include the provision of justice, both in the form of an equitable labor exchange (distributive justice) and the members' ability to have a voice in important union decisions (procedural justice). Because wages are determined jointly by the union and the employer, union leaders will have less control over distributive justice (in this case, wage equity) than they will have over the delivery of procedural justice. Despite the employer's ability to constrain wage settlements, however, the union's role in negotiating a fair wage can be substantial, so at least part of the credit for members' experience of distributive justice belongs

\footnotetext{
${ }^{5}$ The union locals included in this study are members of the National Education Association and are characterized by a commitment to achieving strong wages, hours, and working conditions, and professional advocacy. While many of the members do not see themselves as trade unionists per se, their overall levels of commitment to their association are high, and they do bargain to achieve and protect contract gains.
} 
to the union. The empirical link between proceduraland distributive justice is well established (see Greenberg, 1996, for summaries), supporting the theoretical argument that perceptions of fair procedures lead to perceptions of fair outcomes (Leventhal, 1976; Thibault \& Walker, 1975). Given the centrality of the union contract to union members, we argue that it matters how union presidents determine the union's contract proposals. We therefore examine the relationships between how union presidents fulfill their leadership obligations and members' perceptions of union instrumentality for both wages and non-wage outcomes, wage equity, and procedural justice, as well as the more global constructs of union commitment and participation. We model the relationships between the union president's leadership and the members' perceptions of, and attitudes toward, their union with the following outcome variables: union instrumentality for wages and non-wage outcomes (to capture the noneconomic conditions of employment), wage equity (distributive justice), fairness of procedures used to determine wage scales (procedural justice), union commitment, and union participation.

Members' beliefs about union instrumentality, fair treatment by the union, and wage equity are based on combinations of the union's ability to deliver at the bargaining table, the leaders' ability to ensure that the employer adheres to contract provisions, the help or service they receive from union officials, their own engagement in the union, as well as what they are told about the union's role in negotiating and policing the contract. Both internally and externally focused leadership should be related to instrumentality perceptions because the purpose of both is to increase the utility of the local to the members. The relationship is obvious with respect to externally focused leadership. We suggest that internally focused leadership will also contribute to instrumentality perceptions, however, because the day-to-day functions of local union leadership consist of helping members solve workplace conflicts and problems. We therefore expect that presidents with a problem solving or service orientation will strengthen the members' beliefs about the utility of the union.

Understanding the relationships between the union president's behavior and members' perceptions of fair treatment requires an analysis of why justice is important and how it affects attitudes and behaviors. Justice has instrumental value, in the sense that fair processes are more likely to result in outcomes we prefer (Lind \& Tyler, 1988; Thibault \& Walker, 1975). Being treated fairly also tells us that we are respected, valued, and included members of a group or an organization (Lind, 2001; Tyler \& Blader, 2000). Finally, for many, obtaining and providing justice is a moral principle (Deutsch, 1975; Folger, 1998). Cognitive and affective responses to fair treatment include gratitude toward, and trust in, the justice provider, a sense of group pride and belongingness, and an obligation to reciprocate (Cropanzano, Rupp, Mohler, \& Schminke, 2001). According to social exchange theory (e.g., Blau, 1986; Organ, 1990) and the group-value model of justice (Lind \& Tyler, 1988), positive affect, the desire to remain in close interpersonal relationships, and the motivation to work for the benefit of the group or collectivity link justice perceptions to outcomes like organizational citizenship behavior (e.g., Colquitt, Conlon, Wesson, Porter, \& Ng, 2001; Konovsky \& Pugh, 1994; Organ, 1990) and organizational commitment (Konovsky \& Cropanzano, 1991; Masterson, Lewis, Goldman, \& Taylor, 2000). The effects are stronger for procedural justice than for distributive justicebecause perceptions of distributive justice stem from an outcome's instrumental value whereas procedural justice has both instrumental and relational roots (Cropanzano et al., 2001). 
It is also possible that the effect of distributive justice is even weaker for union outcomes since members may not attribute the responsibility for fair outcomes solely to union leadership.

The large amount of data testifying to organizational consequences of justice comes from studies of employment relationships, but the psychological processes that explain the findings will operate in unions as well (e.g., Aryee \& Chay, 2001; Fuller \& Hester, 2001; Johnson \& Jarley, 2004). The relationship between the union and its members has been described as a psychological contract that prescribes the exchange of members' commitment and participation for bargaining outcomes and social inclusion (Gordon \& Fryxell, 1993; Shore, Tetrick, Sinclair, \& Newton, 1994; Tetrick, 1995). In the context of our study, a relationship of union involvement with wage equity would result from an economic exchange, and a relationship with the process used to determine union wage goals would stem from both an economic and a social exchange.

Internally focused leadership should be related to members' perceptions of procedural justice because it includes being given a voice in determining the union's bargaining goals either through simple exchanges of information with the president about contract negotiations or by being formally or informally included in union decision making. Externally focused leadership should contribute to members' beliefs about distributive justice (wage equity) because wages depend on what the union obtains in bargaining.

We test the following hypotheses:

Hypothesis 1: The time and effort union presidents expend on internally focused union activities will be positively related to members' perceptions of

(a) wage and non-wage outcomes instrumentality and

(b) procedural justice.

Hypothesis 2: The time and effort union presidents expend on externally focused union activities will be positively related to members' perceptions of

(a) wage and non-wage outcomes instrumentality and

(b) wage equity (distributive justice).

Prior studies have tested hypotheses about the causal paths between leadership and union commitment and participation. We are not proposing a new model of the union leadermember involvement relationship, but we expect this relationship to be mediated by members' perceptions of instrumentality and justice. The relationships between what union leaders do and the behavioral components of union commitment (willingness to work for, and responsibility to, the union) and participation in the union are not straightforward. The relationships could be negative if the union leaders are effective as external managers because with a favorable contract and cordial labor-management relations, members may feel no pressing need to get involved to fix what is not broken. On the other hand, internally focused leadership might succeed in pulling the members into active duty even if their 
conditions of employment are satisfactory. The social exchange and group-value theories suggest that the members' motivation to reciprocate fair treatment from union leaders would lead to union involvement.

Because internally focused leadership includes both the president's efforts to serve members and his or her efforts to educate and involve them, we expect this focus to be related to both the affective and behavioral components of union commitment and participation, partly conditional on the relationship between the president's behavior and members' perceptions of instrumentality and procedural justice. Externally focused leadership, on the other hand, is not aimed at turning rank-and-file members into active trade unionists, so we expect it to be important primarily for union loyalty through the members' recognition and appreciation of the union's role in securing valued outcomes.

Hypothesis 3: The relationship between union presidents' internally focused leadership and members' union commitment will be partially mediated by members' perceptions of union instrumentality and procedural justice.

Hypothesis 4: The relationship between union presidents' externally focused leadership and members' loyalty to the union will be mediated by members' perceptions of union instrumentality and distributive justice.

There are a number of contextual variables that are likely to contribute to union members' beliefs about instrumentality and justice, commitment and participation, the most obvious being bargaining outcomes. We therefore control for employer munificence and wages when testing the hypotheses. Because local union size and the quality of union-management relations have been found to be related to union commitment in earlier studies, we include measures of both in the equations, as well as standard demographic variables.

\section{Samples and Procedures}

\section{Method}

The data used in this study come from a large project on local union effectiveness that included union leadership, union commitment, and wage bargaining. Subjects were 326 presidents and 4,363 public school teachers in grades $\mathrm{K}-12$ from union locals (local associations), and 51 state-level staff members of the National Education Association. The union locals comprised $65 \%$ of the 501 school districts in a northeastern state that has a compulsory bargaining law. The primary data came from surveys that were supplemented with financial, demographic, and salary information from the state education association's archives. The state association randomly selected members from each of the locals for inclusion in the study, with the number of subjects determined by the size of the local.

The surveys were sent to 14,388 union members from the state association's headquarters because the association did not want to release members' names and addresses. Of these, 4,668 were returned for a response rate of $30 \%$. Code numbers were used to identify respondents by union local and to match survey responses to the demographic and salary data. Each survey was accompanied by two letters, one from the president of the state association endorsing the study and one from the researchers describing the purpose of the study and the 
procedures used to ensure confidentiality of responses, as well as a postage paid envelope to return completed surveys to the researchers at their university. A comparison of the school districts and teachers in the sample with districts and teachers in the state showed that at the district- (or union-local-) level of analysis, the state and sample means on organizational, demographic, and economic variables were similar. ${ }^{6}$

\section{Measures}

The data used in the hypothesis tests came from three sources: union members, union staff, and union archives. ${ }^{7}$ We describe the union leadership variables first, followed by outcome and control variables. Most of the measures, except the leadership scales, were previously designed and validated scales.

\section{Explanatory Variables}

Union leadership. Information about union presidents' behavior was collected from the union members and union field staff.

Internal leadership. The measures of internal (within-union focused) leadership were provided by the union members who described, on a 5-point verbally anchored scale, how often their union president engaged in each of 12 activities directed at solving problems for, consulting with, and informing union members (from almost never to almost all the time). Scale content was based on interviews with state association staff and local association presidents, and it included items from Nicholson et al.'s (1980) measure of service orientation. Because we theorized that union leadership was an organizational-level multi-dimensional construct, we conducted a multi-level confirmatory factor analysis (CFA) to examine the structure of the scale at both the individual and local union level. We followed the recommended method of Dyer, Hanges, and Hall (2005) and first examined intraclass correlations (ICCs) at the item level. All ICCs were between 10 and 17 , which suggested that there was considerable variation at the local union level, justifying aggregation. We then tested the measurement model with three first-order factors and a second-order leadership factor at both levels. All items (see the Appendix for the items) loaded significantly on their respective factors, and the first-order factors loaded significantly in the second-order factor at both levels. The model fit the data well, $x^{2}\left(102, N_{\text {Level } 1}=2,334 ; N_{\text {Level } 2}=293\right)=651.7$ (comparative fit index $[\mathrm{CFI}]=.97$, Tucker-Lewis index $[T L I]=.97$, root-mean-square error of approximation [RMSEA] $=.048$, squared root-mean residual $[S R M R]_{\text {between }}=.045, S R M R_{\text {within }}=.022$ ). The ICC1 value for the leadership scale was .13 , and the ICC2 value was 70 .

We calculated the $r w g(j)$ for the scale (James, Demaree, \& Wolf, 1984) for all local unions in the sample. The median $r w g(j)$ was .95. An examination of $r w g(j)$ for each local union showed that out of 295 locals, 244 had $r w g(j)$ scores above .90 . There were only 15 local unions with $r w g(j) s$ that were below the .70 mark that has been suggested as a heuristic. Of these, 8 were between .00 and .70 , and 7 were outside of the range of $r w g(j) s$ (either negative or above 1). A number of the 15 local unions with no agreement were not part of the sample used in the analysis because we did not have matching data on union characteristics. Dropping the small number of other unions with no agreement did not change the results. Therefore, all items

\footnotetext{
${ }^{6}$ District size (enrollment figures) were 2,844 for the state and 2,661 for the sample; a school district wealth indicator was 49 for the state and 50 for the sample; teacher experience was 16.4 years for the state and 16.5 years for the sample; and teacher post-secondary education attainment was 5.7 years for the state and 5.7 years for the sample.

${ }^{7}$ Union presidents provided information about the time requirements of different leadership functions that were not used in the present study.
} 
were combined in one scale $(\alpha=.95)$, and the scale score was aggregated to the local union level with union ID numbers.

External leadership. Data on externally focused leadership came from the state association field staff who described the extent to which the presidents of the locals in the geographical part of the state they supervised engaged in six activities. Subjects rated their responses on a 5-point, verbally anchored, agree-disagree scale ranging from 1 (strongly disagree) to 5 (strongly agree). Each item was a statement beginning with the phrase "The local president." The items were the following: (a) "builds external political support for teachers and education by creating alliances with community organizations, working to elect pro-education candidates for political office, and/or generating political action contributions from members"; (b) "prepares for negotiations externally by monitoring negotiations in the region and state and by participating in coordinated bargaining"; (c) "administers the local union by maintaining accurate records, preparing administrative reports on time, allocating sufficient time to accomplish high priority tasks, responding to requests of individual members, and monitoring school board meetings"; (d) "makes long-range, strategic plans for the local association with respect to such issues as membership goals, future bargaining goals, how to respond to future fiscal or political problems, a discontented citizenry, education reform"; (e) "works to involve the local union in initiatives to improve the quality of education in the school district"; and (f) "communicates clearly and adequately with the state association representative." All items loaded on one factor and were combined in one scale $(\alpha=.89)$. No aggregation was necessary since each president was rated by only one member of the field staff. ${ }^{8}$

All the other variables used in the study were measured with 5-point, verbally anchored scales, unless otherwise indicated. The scales had items in statement form to which subjects were asked to agree or disagree. Response alternatives ranged from 1 (strongly disagree) to 5 (strongly agree).

\section{Outcome Variables}

Union commitment. Nineteen items from the 30-item Commitment scale developed by Gordon, Philpot, Burt, Thompson, and Spiller (1980) were used to measure union loyalty, willingness to work for the union, and responsibility to the union. We included the strongest items (those with the highest factor loadings) from the original scales and excluded items that did not fit well with a teacher's union. Bayazit, Hammer, and Wazeter (2004) showed that the negatively worded items created a method artifact, and the authors suggested that this method variance should be dealt with before testing theoretical relationships. We therefore used factor scores that were estimated by using a three-factor CFA with a fourth orthogonal methods factor. The measure contained nine loyalty items ( $\alpha=.92)$, four willingness items $(\alpha=.82)$, and four responsibility items ( $\alpha=.72$ ).

Participation in the union. Participation in the union was measured with a scale developed by McShane (1986), which contains five questions that asked if the respondent had, in the last 2 years, run for elected office or held a local union position, served on a local

\footnotetext{
${ }^{8}$ ICC1 for the external leadership measure indicating interdependence between ratings of different local presidents by the same staff member was .18. To control for this interdependence, we ran a three-level analysis where the staff members as raters of multiple local presidents' external focus were at the third level. The results of these analyses did not change the results from the hypothesis tests. We therefore report results of HLM analyses using two levels for reasons of parsimony. The results of the three-level analyses are available from Tove Helland Hammer on request.
} 
committee, gone to a union meeting, represented the local at a state or regional meeting or a convention, and/or filed a grievance through the local. We added a sixth item, asking whether the respondent had participated in a coffee klatch (a community relations activity unique to teachers' unions) or other community related work for the local. Respondents answered yes or no to each question, and responses were summed to make a union involvement or participation index. Participation is not a conventional latent variable but rather a composite variable (MacCallum \& Browne, 1993) or a direct formative measure (Edwards \& Bagozzi, 2000). That is, the construct is formed by direct linear combinations of its indicators or component measures. In composite variables, high correlations between specific components are not expected, and therefore causal indicators need not be internally consistent (Bollen \& Lennox, 1991). Hence, we believe the measurement error of the participation variable can be ignored.

Union instrumentality for wages. Union instrumentality for wages was measured with three items. One came from Martin and Peterson's (1987) study of two-tier wage systems, "The local association has helped us obtain fair pay." The others were designed for this study and asked how satisfied the respondents were with the their local association's role in getting better wages and in getting better fringe benefits for members. These items were measured on a scale ranging from 1 (very satisfied) to 5 (very dissatisfied), with $\alpha=.84$.

Union instrumentality for non-wage outcomes. Union instrumentality for non-wage outcomes was measured with a three-item scale. The scale asked members how satisfied they were with their local association's role in improving job security, getting the employer to improve the physical work environment, and making work more intrinsically enjoyable ( $\alpha=.76)$.

Distributive justice (or wage equity). Distributive justice (or wage equity) was measured with an adaptation of Folger and Konovsky's (1989) two-item Distributive Justice scale. Items for this scale were "My salary gives me the full amount I deserve," and "The size of my salary is fair" $(\alpha=.86)$.

Procedural justice. Procedural justice was measured with two items from Folger and Konovsky's (1989) Procedural Justice Feedback scale, adapted to teacher salary schedules. Items were "The local association leaders tried to be fair when they negotiated the current salary schedule" and "During the last negotiations, the local association leaders were willing to consider my views regarding the salary schedule" ( $\alpha=. .76)$.

To test for discriminant validity, we subjected all the items of the seven latent outcome variables, except participation, to a seven-factor CFA at the individual level of analysis, $x^{2}$ ( 350 , $N=4,464$ ) $=5,275.024, p<.001$. The fit indices indicated an acceptable level of fit to the data (CFI $=.93, \mathrm{TLI}=.92, \mathrm{RMSEA}=.056, \mathrm{SRMR}=.056$ ). All items loaded significantly on their latent factors. $R 2$ values for the items ranged between a low of .37 and a high of .89 . This seven-factor model was a significantly better fit to the data than was a three-factor model (union commitment, union instrumentality, and justice), $\Delta \mathrm{x}^{2}(2, N=4,464)=12,359, p<.001$.

\section{Control Variables}

In addition to economic and demographic variables, we controlled for the union's relationship with the employer.

Economic and demographic local union characteristics. The following school district data were provided by the state association: financial wealth and student enrollment in the school district. Wealth is a composite index of district wealth based on the personal income and 
property value of citizens in the school district, compiled by the state and used by the state association to assess the financial soundness of school districts.

Relations with employer (school administration). Relations with the employer (school administration) were measured by asking the presidents to describe the nature of the relationship between the local union and the school administration. Ratings were assessed with a nine-item union-management climate scale developed by Kosnik and Brett (1988). The scale covered the agreement that fundamental problems should be solved outside the collective bargaining contract, the degree of cooperation and trust in the union-school administration relationship, and the union's involvement in school governance $(\alpha=.91)$.

Union member characteristics. Salary information was provided for each member by the state association, and information about gender and the number of years a respondent had been a union member was available from the member surveys.

\section{Statistical Analyses: Model Descriptions}

In this study, individuals are clustered within local unions. To examine the level of nonindependence in the data, we calculated ICC1 for the outcome variables applied to the union members. ICC1 values were $23 \%$ for wage instrumentality, $10 \%$ for nonwage outcomes instrumentality, $20 \%$ for wage equity (distributive justice), and $11 \%$ for procedural justice. The ICC1 values for the union commitment subscales and union participation were as follows: $9.3 \%$ for union loyalty, $2.7 \%$ for responsibility to the union, $5.1 \%$ for willingness to work for the union, and $7.3 \%$ for union participation. This meant that there was sufficient between-union variance in members' perceptions of union instrumentality, distributive and procedural justice, union loyalty, willingness to work for the union, and participation to analyze the data with hierarchical linear models (HLMs; Raudenbush \& Byrk, 2001). Strictly speaking, the nearly $3 \%$ betweenunion variance in responsibility was sufficiently significant to warrant multi-level modeling, but there was, of course, much less between-level variance to explain. However, we did test an HLM model with two levels for each of the eight outcome variables.

For each of the outcome models, Level 1 is the individual rank-and-file member level that contains gender, number of years as a union member, and salary (all fixed effects). ${ }^{9}$ Level 2 is the local union level, which contains school district size and wealth as well as unionemployer relations and the members' leadership descriptions (aggregated to the local union level). In a separate set of models, the leadership ratings supplied by the field staff were used. The variables were entered in the following steps: economic and demographic controls, individual-level explanatory variables, and union-level explanatory variables. In the equations, the number of union locals are reduced somewhat from the original sample by the demands for complete data and a sufficiently large number of within-union respondents for reliable aggregation.

We followed the procedures recommended by Mathieu and Taylor (2007) and Krull and McKinnon $(1999,2001)$ to test our multi-level mediation hypotheses with lower-level mediators (members' perceptions of union instrumentality and justice). Accordingly, we first examined ICC values for both mediators and outcome variables (the three union commitment dimensions and union participation). Second, we computed multi-level regressions predicting the mediators by control variables as well as internal and external leadership. Third, we computed multi-level

\footnotetext{
${ }^{9}$ There was no theoretical reason to expect variations in slopes across local unions for these variables.
} 
Table 1

Descriptive Statistics, Intra-Class Correlations (ICCs), and Correlation Coefficients for Explanatory and Outcome Variables

\begin{tabular}{|c|c|c|c|c|c|c|c|c|c|c|c|c|c|c|c|c|c|c|c|c|}
\hline Variable & $M$ & $S D$ & $\mathrm{ICC} 1$ & $\mathrm{ICC} 2$ & 1 & 2 & 3 & 4 & 5 & 6 & 7 & 8 & 9 & 10 & 11 & 12 & 13 & 14 & 15 & 16 \\
\hline 1. Gender ${ }^{\mathrm{a}}$ & 1.33 & 0.47 & & & - & .23 & .05 & -.04 & -.15 & .03 & -.14 & -.14 & -.19 & -.18 & -.15 & -.03 & .10 & .01 & -.13 & .16 \\
\hline 2. Union tenure & 15.39 & 8.21 & & & .26 & - & .54 & .10 & .01 & -.05 & -.07 & .03 & -.13 & .03 & .03 & .08 & .25 & .11 & -.03 & .11 \\
\hline 3. Salary $(\log )$ & 4.48 & 0.10 & & & .19 & .69 & - & .43 & .58 & .08 & .05 & .40 & .02 & .31 & .09 & -.06 & -.02 & -.04 & .01 & .20 \\
\hline 4. District size $(\log )$ & 3.49 & 0.29 & & & -.02 & .00 & .24 & - & .19 & .05 & .02 & .25 & .11 & .18 & .09 & -.31 & -.29 & -.40 & .12 & .27 \\
\hline 5. District wealth & 0.54 & 0.28 & & & -.04 & -.01 & .38 & .17 & - & .16 & .21 & .33 & .24 & .31 & .15 & -.07 & -.17 & -.09 & .12 & .08 \\
\hline 6. Employer-union relations & 3.31 & 0.81 & & & .00 & -.02 & .05 & .09 & .14 & - & -.03 & .22 & .24 & .15 & .09 & .02 & -.06 & -.11 & -.07 & -.03 \\
\hline 7. Procedural justice & 3.73 & 0.88 & .11 & .66 & -.05 & .04 & .09 & .01 & .09 & .00 & - & .40 & .49 & .67 & .65 & .33 & .03 & .04 & .65 & .22 \\
\hline 8. Wage equity & 2.67 & 1.05 & .21 & .80 & -.07 & .04 & .20 & .11 & .16 & .07 & .35 & - & .52 & .77 & .42 & .11 & -.17 & -.14 & .30 & .26 \\
\hline 9. Union instrumentality (nw) & 3.20 & 0.77 & .10 & .63 & -.07 & .04 & .05 & .05 & .12 & .08 & .43 & .36 & - & .62 & .63 & .26 & -.13 & -.12 & .55 & .19 \\
\hline 10. Union instrumentality (w) & 3.74 & 0.87 & .23 & .83 & -.10 & .03 & .16 & .09 & .17 & .06 & .63 & .59 & .53 & - & .64 & .24 & -.09 & -.12 & .52 & .27 \\
\hline 11. Loyalty & 3.80 & 0.74 & .08 & .57 & -.06 & .11 & .09 & .04 & .06 & .03 & .55 & .22 & .51 & .52 & - & .62 & .26 & .03 & .73 & .26 \\
\hline 12. Willingness to work & 3.26 & 0.80 & .05 & .45 & .05 & .14 & .07 & -.12 & -.03 & -.02 & .30 & -.01 & .22 & .21 & .63 & - & .58 & .49 & .34 & .03 \\
\hline 13. Responsibility & 3.95 & 0.60 & .03 & .32 & .11 & .20 & .10 & -.10 & -.06 & -.04 & .17 & -.12 & .07 & .05 & .46 & .63 & - & .32 & .05 & -.05 \\
\hline 14. Participation & 9.03 & 1.53 & .08 & .59 & .09 & .23 & .16 & -.17 & -.02 & -.05 & .13 & -.08 & .02 & .03 & .22 & .49 & .34 & - & .00 & -.10 \\
\hline 15. Internal leadership & 3.76 & 0.78 & .13 & .70 & -.08 & .01 & .02 & .06 & .07 & -.02 & .52 & .23 & .51 & .47 & .63 & .31 & .19 & .07 & - & .37 \\
\hline 16. External leadership & 3.89 & 0.68 & & & .04 & .03 & .13 & .32 & .10 & .05 & .09 & .15 & .09 & .16 & .09 & .01 & -.02 & -.06 & .16 & - \\
\hline
\end{tabular}

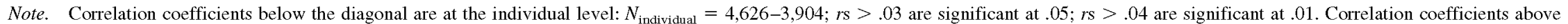
the diagonal are at the local union level: $N_{\text {group }}=247 ; r s>.12$ are significant at $.05 ; r s>.17$ are significant at .01 . nw $=$ non-wage outcomes; w $=$ wage outcomes.

${ }^{\mathrm{a}} 1$ = female; 2 male. 
regressions predicting the outcome variables by using control variables and internal and external leadership. Fourth, we estimated the same coefficients conditional on the mediators. Finally, we calculated the mediating effects and corresponding standard errors of internal and external leadership on the outcome variables.

\section{Results}

Descriptive statistics, ICCs, and correlation coefficients for both individual member and union levels are provided in Table 1. Internal and external leadership were positively correlated at the union level (.37), which suggests that the two leadership variables are related but conceptually distinct from each other. With respect to the control variables, we note that salary is positively correlated with wage equity at the individual level (.20) and the union level (.40) as well as with members' perceptions of union instrumentality for wage outcomes (.16 and .31, respectively). District size, a close correlate of local union size, was correlated with externally focused union leadership (.32 and .27 at the individual and union levels, respectively). Of the survey data, instrumentality and justice perceptions were positively intercorrelated and were related to union loyalty in particular. The three union commitment dimensions were also positively correlated. Union participation was positively correlated with union commitment, the strongest relationship being, naturally enough, with members' willingness to work for the union (.49).

To test the first set of hypotheses, we regressed internal and external leadership on union instrumentality and justice variables by using HLM. The results are shown in Table 2 . For each outcome variable, all the control variables (the individual-level demographic variables, the union characteristics, and employer- union relations) were entered in Step 1 and internal leadership at Step 2. In a third model, we entered externally focused leadership at Step 2.

Internally focused leadership had, as hypothesized, a significant positive coefficient ( $B=$ $0.68, p<.001$ ) and explained $32 \%$ of variance at the local union level in members' perceptions of union instrumentality for wages after controlling for individual- and union-level control variables. This amounted to $7 \%$ of the total variance in the wage instrumentality variable.

Internal leadership was also significantly related to union instrumentality for non-wage outcomes $(B=0.51, p<.001)$. Adding internal leadership to the equation increased the union level pseduo- $R^{2}$ by $48 \%$, after controlling for individual- and union-level control variables. This is equivalent to around $5 \%$ of the total variance in the union instrumentality for the non-wage outcomes variable. These results provide strong support for Hypothesis 1a.

Hypothesis $1 \mathrm{~b}$ stated that internally focused leadership would be positively related to members' perceptions of procedural justice. As can be seen in Table 2, the internal leadership coefficient is significant $(B=0.66, p<.001)$. Adding internal leadership to the model increased the union-level pseudo- $R^{2}$ by $55 \%$, which equals about $6 \%$ of the total variance in procedural justice, supporting the hypothesis.

Hypotheses $2 \mathrm{a}$ and $2 \mathrm{~b}$ described the relationship between the union president's externally focused leadership and members' perceptions of union instrumentality and wage equity (distributive justice), respectively. Hypothesis 2a stated that external leadership will be positively related to instrumentality for both wage and non-wage outcomes. The results, shown 
Table 2

Summary of Hierarchical Multilevel Analysis: Dependent Variables are Union Instrumentality Beliefs, Procedural Justice, and Wage Equity

\begin{tabular}{|c|c|c|c|c|c|c|c|c|c|c|c|c|}
\hline \multirow[b]{3}{*}{ Variable } & \multicolumn{6}{|c|}{ Instrumentality (wage) } & \multicolumn{6}{|c|}{ Instrumentality (non-wage) } \\
\hline & \multicolumn{2}{|c|}{ Model 1} & \multicolumn{2}{|c|}{ Model 2} & \multicolumn{2}{|c|}{ Model 3} & \multicolumn{2}{|c|}{ Model 1} & \multicolumn{2}{|c|}{ Model 2} & \multicolumn{2}{|c|}{ Model 3} \\
\hline & $B$ & $\begin{array}{l}\text { Robust } \\
\qquad S E\end{array}$ & $B$ & $\begin{array}{l}\text { Robust } \\
\text { SE }\end{array}$ & $B$ & $\begin{array}{l}\text { Robust } \\
\qquad S E\end{array}$ & $B$ & $\begin{array}{l}\text { Robust } \\
\qquad S E\end{array}$ & $B$ & $\begin{array}{l}\text { Robust } \\
\qquad S E\end{array}$ & $B$ & $\begin{array}{c}\text { Robust } \\
S E\end{array}$ \\
\hline \multicolumn{13}{|c|}{ Step 1} \\
\hline Gender & $-0.21^{* * *}$ & 0.03 & $-0.20^{* * *}$ & 0.03 & $-0.21^{* * *}$ & 0.03 & $-0.11^{* * *}$ & 0.03 & $-0.10^{* * *}$ & 0.03 & $-0.11^{* * *}$ & 0.03 \\
\hline Union tenure & $-0.007^{*}$ & 0.003 & $-0.008^{* *}$ & 0.003 & $-0.007^{*}$ & 0.003 & $0.009^{* *}$ & 0.003 & $0.008^{* *}$ & 0.003 & $0.009^{* *}$ & 0.003 \\
\hline Salary (log) & $1.47^{\text {水水 }}$ & 0.26 & $1.64^{\text {水水 }}$ & 0.25 & $1.45^{\text {隶水 }}$ & 0.26 & -0.28 & 0.23 & -0.22 & 0.22 & -0.31 & 0.23 \\
\hline District size $(\log )$ & 0.12 & 0.11 & 0.01 & 0.10 & 0.00 & 0.11 & 0.09 & 0.08 & 0.01 & 0.07 & 0.04 & 0.09 \\
\hline District wealth & $0.29^{* *}$ & 0.10 & 0.16 & 0.10 & $0.27^{* *}$ & 0.10 & $0.29^{* *}$ & 0.08 & $0.20^{* *}$ & 0.07 & $0.28^{* * *}$ & 0.08 \\
\hline Employer-Union & & & & & & & & & & & & \\
\hline relations & 0.05 & 0.03 & $0.07^{\text {冰 }}$ & 0.03 & 0.05 & 0.03 & $0.07^{\text {隶 }}$ & 0.02 & $0.09^{\text {承水 }}$ & 0.02 & $0.07^{\text {承 }}$ & 0.02 \\
\hline Pseudo $R^{2}$ (within) & $2 \%$ & & & & & & $1 \%$ & & & & & \\
\hline Pseudo $R^{2}$ (between) & $19 \%$ & & & & & & $16 \%$ & & & & & \\
\hline$\Delta \chi^{2}\left(d f_{\mathrm{s}}=6\right)$ & $118^{* * *}$ & & & & & & $56^{* * *}$ & & & & & \\
\hline \multicolumn{13}{|c|}{ Step 2} \\
\hline Internal leadership & & & $0.68^{* * *}$ & 0.08 & & & & & $0.51^{* * *}$ & 0.05 & & \\
\hline Pseudo $R^{2}$ (within) & & & $2 \%$ & & & & & & $1 \%$ & & & \\
\hline Pseudo $R^{2}$ (between) & & & $51 \%$ & & & & & & $64 \%$ & & & \\
\hline$\Delta \chi^{2}(d f s=1)$ & & & $91^{\text {氷水 }}$ & & & & & & $101^{\text {我承 }}$ & & & \\
\hline External leadership & & & & & $0.17^{\text {** }}$ & 0.05 & & & & & $0.08^{*}$ & 0.03 \\
\hline Pseudo $R^{2}$ (within) & & & & & $2 \%$ & & & & & & $1 \%$ & \\
\hline Pseudo $R^{2}$ (between) & & & & & $25 \%$ & & & & & & $21 \%$ & \\
\hline$\Delta \chi^{2}(d f s=1)$ & & & & & $16^{* * \cdots}$ & & & & & & $7.1^{\text {隶 }}$ & \\
\hline
\end{tabular}


Table 2

(Continued)

\begin{tabular}{|c|c|c|c|c|c|c|c|c|c|c|c|}
\hline \multicolumn{6}{|c|}{ Procedural justice } & \multicolumn{6}{|c|}{ Wage equity } \\
\hline \multicolumn{2}{|c|}{ Model 1} & \multicolumn{2}{|c|}{ Model 2} & \multicolumn{2}{|c|}{ Model 3} & \multicolumn{2}{|c|}{ Model 1} & \multicolumn{2}{|c|}{ Model 2} & \multicolumn{2}{|c|}{ Model 3} \\
\hline \multicolumn{12}{|c|}{ Step 1} \\
\hline 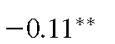 & 0.03 & $-0.10^{\text {宷秋 }}$ & 0.03 & $-0.11^{* *}$ & 0.03 & $-0.18^{\text {氷水 }}$ & 0.04 & $-0.18^{* * * k}$ & 0.04 & $-0.18^{\text {承水 }}$ & 0.04 \\
\hline-0.11 & 0.09 & $-0.19^{*}$ & 0.08 & $-0.19^{*}$ & 0.09 & 0.23 & 0.13 & 0.20 & 0.12 & 0.12 & 0.13 \\
\hline $0.17^{\text {* }}$ & 0.08 & 0.05 & 0.07 & $0.16^{*}$ & 0.08 & $0.23^{*}$ & 0.11 & -0.14 & 0.10 & $0.21^{*}$ & 0.10 \\
\hline-0.02 & 0.02 & 0.01 & 0.02 & -0.02 & 0.02 & $0.10^{* *}$ & 0.03 & $0.11^{* * *}$ & 0.03 & $0.10^{* *}$ & 0.03 \\
\hline $1 \%$ & & & & & & $2 \%$ & & & & & \\
\hline $4 \%$ & & & & & & $26 \%$ & & & & & \\
\hline & & $59 \%$ & & & & & & $37 \%$ & & & \\
\hline & & $122^{\text {*** }}$ & & & & & & $28^{* * *}$ & & & \\
\hline & & & & $0.11^{* *}$ & 0.04 & & & & & $0.15^{* *}$ & 0.04 \\
\hline & & & & $1 \%$ & & & & & & $2 \%$ & \\
\hline & & & & $10 \%$ & & & & & & $31 \%$ & \\
\hline & & & & $10^{* *}$ & & & & & & $13^{* *}$ & \\
\hline
\end{tabular}

Note. All independent variables are centered around their grand mean. All Level 1 slopes are fixed. Average Level 2 size $=15.7$. Number of Level 2 units $=248$; number of Level 1 units $=3,871 ; \Delta \chi^{2}(d f)=$ chi-square model comparison test based on deviance statistics.

${ }^{*} p<.05 .{ }^{* *} p<.01 .{ }^{* * *} p<.001$. 
Table 3

HLM Analyses of Cross-Level Mediator Effects of Instrumentality Beliefs and Justice Perceptions on the Relationship Between Leadership and Loyalty to the Union

\begin{tabular}{|c|c|c|c|c|c|c|c|c|c|c|}
\hline \multirow[b]{3}{*}{ Variable } & \multicolumn{10}{|c|}{ Loyalty to the union } \\
\hline & \multicolumn{2}{|c|}{ Model 1} & \multicolumn{2}{|c|}{ Model 2} & \multicolumn{2}{|c|}{ Model 3} & \multicolumn{2}{|c|}{ Model 4} & \multicolumn{2}{|c|}{ Model 5} \\
\hline & $B$ & Robust $S E$ & $B$ & Robust $S E$ & $B$ & Robust $S E$ & $B$ & Robust $S E$ & $B$ & Robust $S E$ \\
\hline \multicolumn{11}{|c|}{ Step 1} \\
\hline Gender & $-0.10^{* * *}$ & 0.02 & $-0.10^{* * *}$ & 0.02 & -0.04 & 0.02 & $-0.10^{* * *}$ & 0.02 & $-0.05^{*}$ & 0.02 \\
\hline Union tenure & $0.007^{\text {*** }}$ & 0.002 & $0.006^{\text {T* }}$ & 0.002 & $0.006^{* *}$ & 0.002 & $0.008^{\text {隶 }}$ & 0.002 & $0.007^{\text {*** }}$ & 0.002 \\
\hline Salary $(\log )$ & 0.21 & 0.19 & $0.34^{*}$ & 0.16 & 0.05 & 0.14 & 0.18 & 0.19 & -0.25 & 0.15 \\
\hline District size (log) & 0.04 & 0.06 & -0.04 & 0.04 & 0.01 & 0.03 & -0.01 & 0.07 & 0.04 & 0.04 \\
\hline District wealth & 0.10 & 0.05 & -0.01 & 0.04 & $-0.08^{*}$ & 0.04 & 0.09 & 0.05 & -0.05 & 0.04 \\
\hline Employer-union relations & 0.02 & 0.02 & $0.04^{* *}$ & 0.01 & 0.01 & 0.01 & 0.02 & 0.02 & 0.02 & 0.01 \\
\hline Pseudo $R^{2}$ (within) & $2 \%$ & & & & & & & & & \\
\hline Pseudo $R^{2}$ (between) & $5 \%$ & & & & & & & & & \\
\hline$\Delta \chi^{2}(6)$ & $69^{* * *}$ & & & & & & & & & \\
\hline \multicolumn{11}{|c|}{ Step 2} \\
\hline Internal leadership & & & 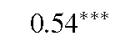 & 0.03 & $0.19^{\text {स*ख }}$ & 0.03 & & & & \\
\hline Pseudo $R^{2}$ (within) & & & $2 \%$ & & & & & & & \\
\hline Pseudo $R^{2}$ (between) & & & $96 \%$ & & & & & & & \\
\hline$\Delta \chi^{2}(1)$ & & & $214^{* * *}$ & & & & & & & \\
\hline External leadership & & & & & & & $0.08^{* * * *}$ & 0.03 & 0.02 & 0.01 \\
\hline Pseudo $R^{2}$ (within) & & & & & & & $2 \%$ & & & \\
\hline Pseudo $R^{2}$ (between) & & & & & & & $14 \%$ & & & \\
\hline$\Delta \chi^{2}(1)$ & & & & & & & $14^{* * *}$ & & & \\
\hline \multicolumn{11}{|c|}{ Step 3} \\
\hline Union instrumentality (w) & & & & & $0.17^{* * *}$ & 0.02 & & & $0.18^{* * *}$ & 0.02 \\
\hline Union instrumentality (nw) & & & & & $0.23^{* * *}$ & 0.02 & & & $0.23^{* * *}$ & 0.02 \\
\hline Procedural justice & & & & & $0.23^{* * *}$ & 0.02 & & & $0.23^{* * *}$ & 0.02 \\
\hline Wage equity & & & & & $-0.09^{* * * * 14}$ & 0.01 & & & $-0.09^{\text {*** }}$ & 0.01 \\
\hline Pseudo $R^{2}$ (within) & & & & & $43 \%$ & & & & $38 \%$ & \\
\hline Pseudo $R^{2}$ (between) & & & & & $81 \%$ & & & & $73 \%$ & \\
\hline$\Delta \chi^{2}(4)$ & & & & & $1,817^{* * *}$ & & & & $1,977^{* * *}$ & \\
\hline
\end{tabular}

Note. All Level 1 slopes are fixed. Average Level 2 size $=15.7$. Number of Level 2 units $=248$; number of Level 1 units $=3,871$. ${ }^{*} p<.05$. $^{* *} p<.01 .^{* * *} p<.001$. 
Table 4

HLM Analyses of Cross-Level Mediator Effects of Instrumentality Beliefs and Justice Perceptions on the Relationships Between Leadership and Willingness, Responsibility, and Participation

\begin{tabular}{|c|c|c|c|c|c|c|c|c|c|c|c|c|c|c|c|c|c|c|}
\hline \multirow[b]{3}{*}{ Variable } & \multicolumn{6}{|c|}{ Willingness to work } & \multicolumn{6}{|c|}{ Responsibility to the union } & \multicolumn{6}{|c|}{ Participation } \\
\hline & \multicolumn{2}{|c|}{ Model 1} & \multicolumn{2}{|c|}{ Model 2} & \multicolumn{2}{|c|}{ Model 3} & \multicolumn{2}{|c|}{ Model 1} & \multicolumn{2}{|c|}{ Model 2} & \multicolumn{2}{|c|}{ Model 3} & \multicolumn{2}{|c|}{ Model 1} & \multicolumn{2}{|c|}{ Model 2} & \multicolumn{2}{|c|}{ Model 3} \\
\hline & B & $\begin{array}{c}\text { Robust } \\
\qquad S E\end{array}$ & $B$ & $\begin{array}{l}\text { Robust } \\
\qquad S E\end{array}$ & $B$ & $\begin{array}{l}\text { Robust } \\
\qquad S E\end{array}$ & $B$ & $\begin{array}{l}\text { Robust } \\
\qquad S E\end{array}$ & $B$ & $\begin{array}{l}\text { Robust } \\
\qquad S E\end{array}$ & $B$ & $\begin{array}{l}\text { Robust } \\
\qquad S E\end{array}$ & $B$ & $\begin{array}{l}\text { Robust } \\
\quad S E\end{array}$ & $B$ & $\begin{array}{l}\text { Robust } \\
\qquad E E\end{array}$ & $B$ & $\begin{array}{c}\text { Robust } \\
\quad S E\end{array}$ \\
\hline & \multicolumn{18}{|c|}{ Step 1} \\
\hline Gender & 0.03 & 0.02 & 0.03 & 0.02 & $0.06^{*}$ & 0.02 & $0.06^{* *}$ & 0.02 & $0.06^{* *}$ & 0.02 & $0.06^{* * *}$ & 0.02 & 0.10 & 0.05 & 0.10 & 0.05 & 0.10 & 0.05 \\
\hline Union tenure & $0.006^{* *}$ & 0.002 & $0.006^{* *}$ & 0.002 & $0.005^{* *}$ & 0.002 & $0.007^{* *}$ & 0.002 & $0.007^{* * *}$ & 0.002 & $0.006^{* * *}$ & 0.002 & $0.02^{* *}$ & 0.005 & $0.02^{* *}$ & 0.004 & $0.02^{* *}$ & 0.005 \\
\hline Salary $(\log )$ & 0.27 & 0.16 & $0.33^{*}$ & 0.16 & $0.36^{*}$ & 0.15 & 0.20 & 0.14 & 0.22 & 0.14 & $0.38^{* *}$ & 0.14 & $2.16^{* * *}$ & 0.41 & $2.19^{* * * *}$ & 0.41 & $2.36^{* * *}$ & 0.40 \\
\hline District size $(\log )$ & $-0.28^{* * *}$ & 0.05 & $-0.32^{* * *}$ & 0.04 & $-0.28^{* * * 4}$ & 0.04 & $-0.17^{* * *}$ & 0.03 & $-0.18^{* * *}$ & 0.03 & $-0.15^{* * *}$ & 0.03 & $-1.00^{* * * *}$ & 0.13 & $-1.01^{1+*}$ & 0.13 & $-0.93^{* * *}$ & 0.13 \\
\hline District wealth & -0.05 & 0.04 & $-0.09^{*}$ & 0.04 & $-0.13^{*}$ & 0.04 & $-0.09^{* *}$ & 0.03 & $-0.10^{* *}$ & 0.03 & $-0.11^{* * *}$ & 0.03 & $-0.21^{*}$ & 0.10 & $-0.23^{*}$ & 0.10 & $-0.23^{* * *}$ & 0.10 \\
\hline Employer-union relations & 0.00 & 0.02 & 0.01 & 0.02 & 0.01 & 0.02 & -0.01 & 0.01 & -0.01 & 0.01 & 0.00 & 0.01 & -0.07 & 0.04 & -0.07 & 0.04 & -0.05 & 0.04 \\
\hline Pseudo $R^{2}$ (within) & $2 \%$ & & & & & & $3 \%$ & & & & & & $5 \%$ & & & & & \\
\hline Pseudo $R^{2}$ (between) & $26 \%$ & & & & & & $52 \%$ & & & & & & $38 \%$ & & & & & \\
\hline \multirow[t]{2}{*}{$\Delta \chi^{2}(6)$} & $92^{* * *}$ & & & & & & $157^{* * *}$ & & & & & & $241^{* * *}$ & & & & & \\
\hline & \multicolumn{18}{|c|}{ Step 2} \\
\hline Internal leadership & & & $0.26^{* * *}$ & 0.03 & $0.08^{*}$ & 0.04 & & & $0.06^{*}$ & 0.02 & 0.00 & 0.03 & & & 0.10 & 0.09 & -0.01 & 0.09 \\
\hline Pseudo $R^{2}$ (within) & & & $2 \%$ & & & & & & $3 \%$ & & & & & & $5 \%$ & & & \\
\hline Pseudo $R^{2}$ (between) & & & $65 \%$ & & & & & & $58 \%$ & & & & & & $39 \%$ & & & \\
\hline \multirow[t]{2}{*}{$\Delta \chi^{2}(1)$} & & & $51^{* * * * *}$ & & & & & & $5^{*}$ & & & & & & 1.2 & & & \\
\hline & \multicolumn{18}{|c|}{ Step 3} \\
\hline Union instrumentality $(\mathrm{w})$ & & & & & $0.08^{* * *}$ & 0.02 & & & & & 0.02 & 0.01 & & & & & 0.04 & 0.05 \\
\hline Union instrumentality (nw) & & & & & $0.11^{* * *}$ & 0.02 & & & & & $0.03^{* *}$ & 0.01 & & & & & 0.00 & 0.04 \\
\hline Procedural justice & & & & & $0.17^{* * *}$ & 0.02 & & & & & $0.11^{* * *}$ & 0.01 & & & & & $0.27^{* * *}$ & 0.04 \\
\hline Wage equity & & & & & $-0.12^{* * *}$ & 0.01 & & & & & $-0.11^{* * *}$ & 0.01 & & & & & $-0.21^{* * *}$ & 0.03 \\
\hline Pseudo $R^{2}$ (within) & & & & & $14 \%$ & & & & & & $10 \%$ & & & & & & $8 \%$ & \\
\hline Pseudo $R^{2}$ (between) & & & & & $48 \%$ & & & & & & $47 \%$ & & & & & & $41 \%$ & \\
\hline$\Delta \chi^{2}(4)$ & & & & & $489^{+* * *}$ & & & & & & $273^{* * *}$ & & & & & & $126^{* * * *}$ & \\
\hline
\end{tabular}

Note. All independent variables are centered around their grand mean. All Level 1 slopes are fixed. Average Level 2 size $=15.7$. Number of Level 2 units $=248 ;$ number of Level 1 units $=3871$. ${ }^{*} p<.05 .{ }^{* *} p<.01 .{ }^{* * *} p<.001$. 


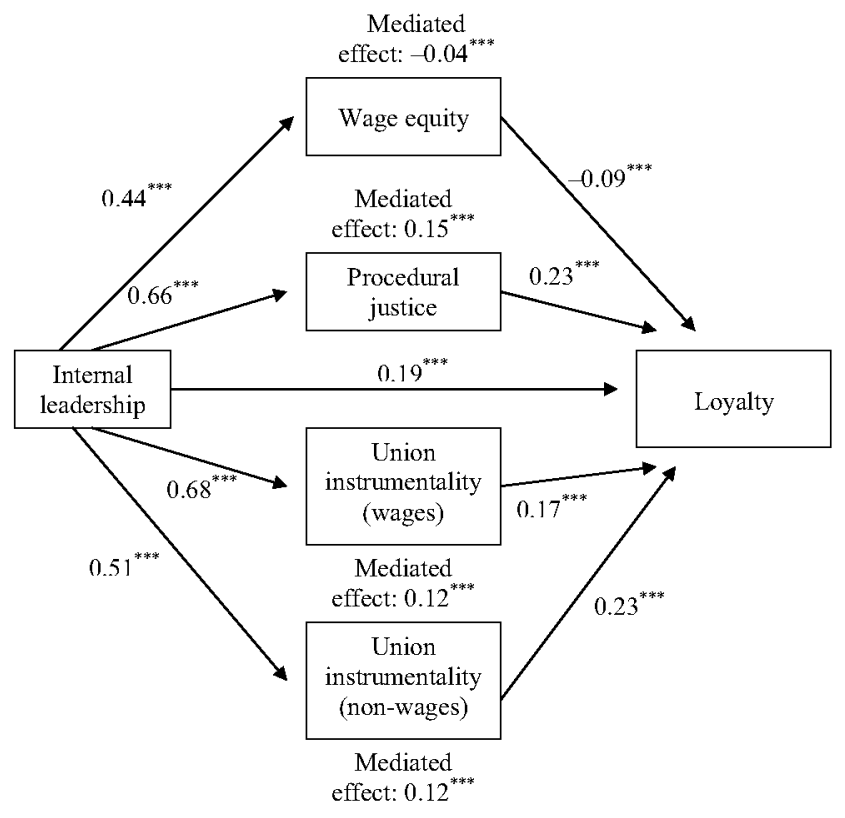

Figure 1. Illustrative model of cross-level mediation: Mediators of the relationship between internal leadership and loyalty to the union. ${ }^{* * *} p<.001$.

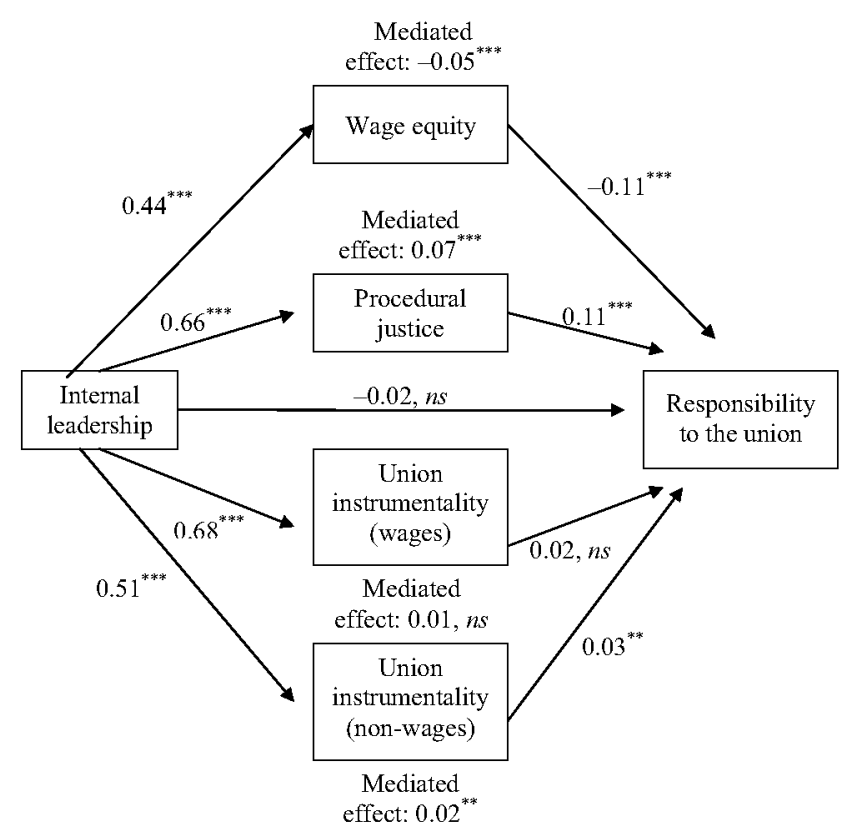

Figure 3. Illustrative model of cross-level mediation: Mediators of the relationship between internal leadership and responsibility to the union. ${ }^{* *} p<.01 .{ }^{* * *} p<.001$. 


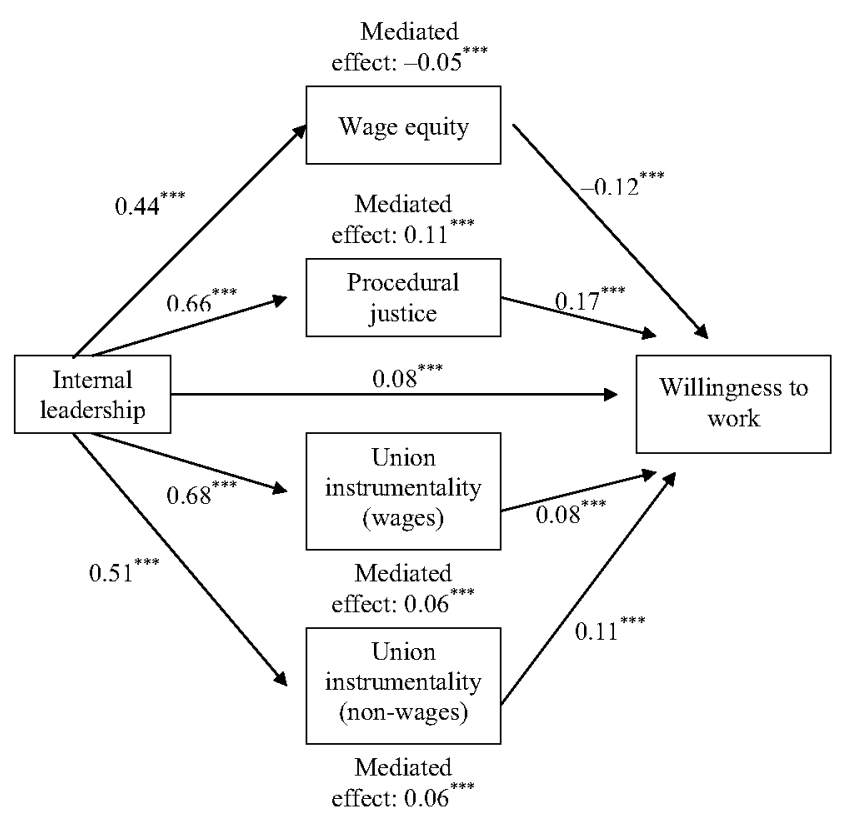

Figure 2. Illustrative model of cross-level mediation: Mediators of the relationship between internal leadership and willingness to work for the union. ${ }^{* * * *} p<.001$.

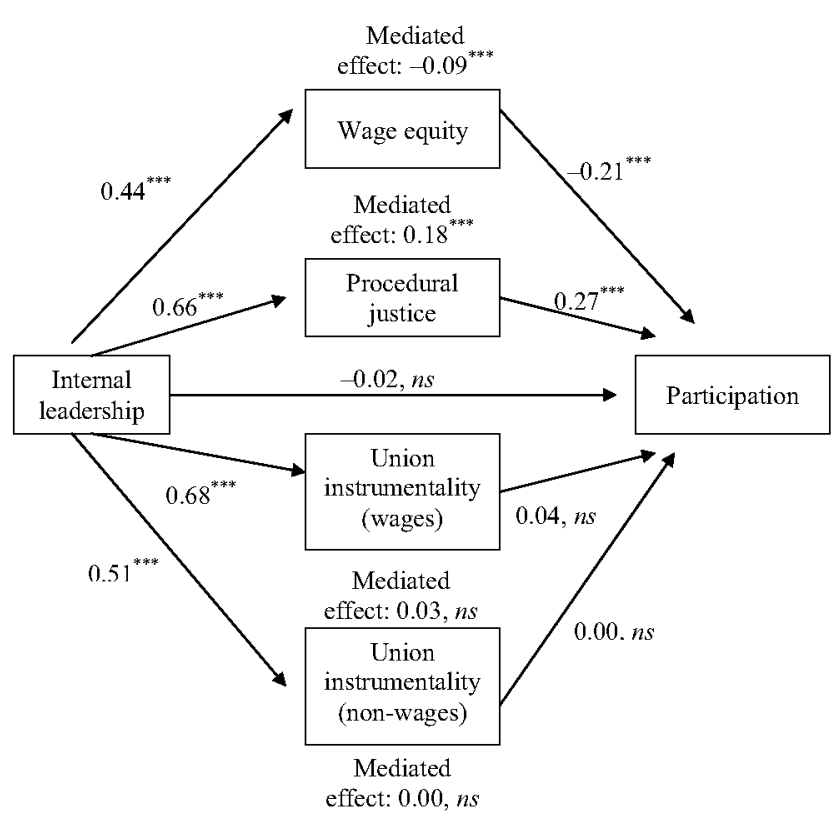

Figure 4. Illustrative model of cross-level mediation: Mediators of the relationship between internal leadership and participation in the union. ${ }^{* * * *} p<.001$. 


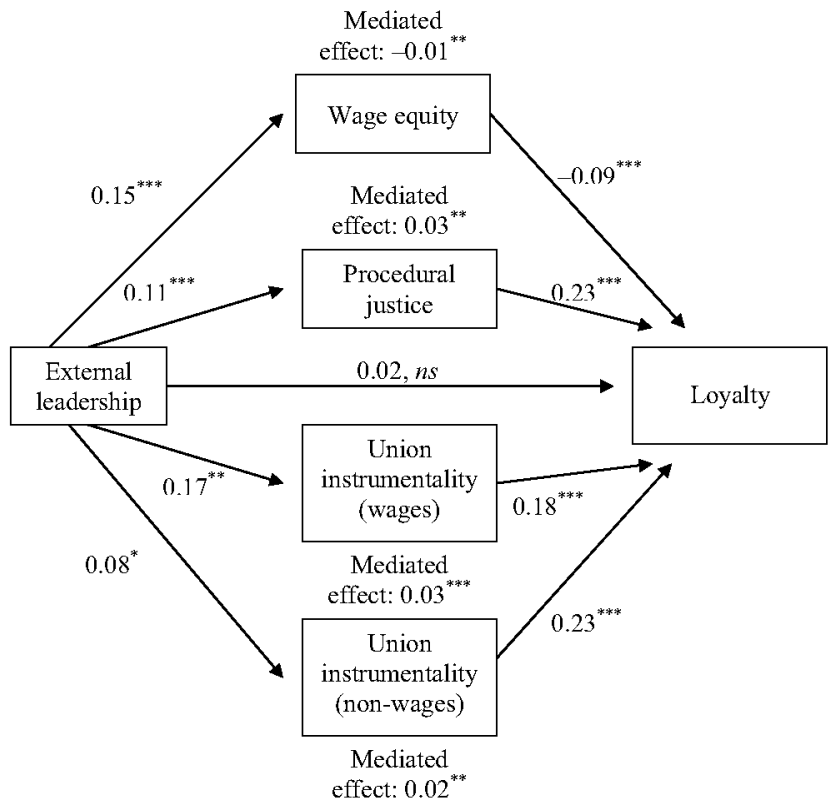

Figure 5. Illustrative model of cross-level mediation: Mediators of the relationship between external leadership and loyalty. ${ }^{*} p<.05 .{ }^{* *} p<.01$. ${ }^{* * * *} p<.001$. 
in the Model 3 columns in Table 2, illustrate that externally focused union leadership contributed positively to the variance in both instrumentality for wages $(B=0.17, p<.01)$ and instrumentality for non-wage outcomes $(B=0.08, p<.05)$. The explained pseudo- $R^{2} s$ were $8 \%$ for wage instrumentality and $2 \%$ for non-wage outcomes instrumentality. These figures amounted to only about $2 \%$ and less than $1 \%$ of the total variance of these variables, respectively. Both are significant, but hardly impressive, additions. The results provide weak support for Hypothesis 2a. In fact, when we ran both of the leadership variables in the same equation, external leadership was no longer significant for either outcome variable.

Hypothesis $2 \mathrm{~b}$ stated that the time and effort union presidents expend on externally focused union activities will be positively related to members' perceptions of wage equity. The results, listed in the last column in Table 2 , supported the hypothesis $(B=0.15, p<.001)$. The addition of external leadership to the equation increased the union-level pseudo- $R 2$ by $5 \%$, which is a significant, but modest, increment that amounts to $1 \%$ of the total variance in the wage equity variable. When both leadership variables were entered in the equation, both external leadership ( $B=0.09, p<.05)$ and internal leadership $(B=0.38, p<.001)$ were significant.

To test Hypotheses 3 and 4 , which described the mediating role of instrumentality and justice perceptions on the leadership- union commitment and leadership-participation relationships, we ran a set of HLMs for each outcome variable to estimate the cross-level mediator effects. As was the case with the previous models, we entered individual- and unionlevel control variables in the first three steps. In the fourth step, we entered the leadership variable and estimated its direct effect $\left(B_{d}\right)$. In the last step, we entered the mediators as one set to estimate the direct effect of leadership after statistically accounting for the mediator effects $\left(B_{d^{\prime}}\right)$. The difference between these two coefficient estimates $\left(B_{d}-B_{d^{\prime}}\right)$ measures the extent to which the mediators as a set account for the relationship between leadership and the outcome variable in question. A full mediation is suggested when $B_{d}$ is significant and $B_{d}$, is zero or close to zero. A partial mediation is suggested when $B_{d}$ is significant and $B_{d^{\prime}}$ decreases in value but is not close to zero (e.g., still significant).

The mediator effect for each mediator is calculated by using the estimates of the effect of leadership $\left(B_{a}\right)$ on the mediator (from Table 2 ) and the estimates of the mediator $\left(B_{b}\right)$ on the outcome variable (from Tables 3 and 4 ). The product of these two estimated coefficients $\left(B_{a} X\right.$ $\left.B_{b}\right)$ is an estimate of the cross-level mediated effect for each hypothesized mediator. The standard errors of these cross-level mediated effects are calculated by using the multi-level first-order Taylor series expansion as recommended by Krull and MacKinnon (1999).

The results of these analyses are presented in Tables 3 and 4 and in Figures 1 through 5. We first describe the results from the tests of Hypothesis 3, which stated that the relationship between union presidents' internally focused leadership and members' commitment to the union will be partially mediated by members' instrumentality perceptions and procedural justice. The results for the affective commitment dimension, union loyalty, are shown in Models 1-3 in Table 3. The coefficient estimated for the internal leadership-loyalty relationship dropped from 0.54 to 0.19 , with no change in its standard error $(S E=0.03)$, once the instrumentality and justice perceptions were entered in the equation. Figure 1shows the crosslevel mediated effects for all three mediators; these were significant and positive. Although wage equity was not part of Hypothesis 3 , we examined its effects as a mediator of the internal leadership- union loyalty as well. It was negative. 
The mediation results for the two behavioral dimensions of union commitment and for union participation are shown in Table 4 and Figures 2-4. Union instrumentality perceptions and procedural justice also partially mediated the relationship between internal leadership and members' willingness to work for their union. The coefficient estimated for the internal leadership- willingness to work relationship dropped from 0.26 to 0.08 , with almost no change in its standard error ( $S E=0.03$ vs. 0.04 , respectively), once the instrumentality and justice perceptions were accounted for (Table 4, first three columns). The cross-level mediator effects for both union instrumentality perceptions and procedural justice were significant and positive, but the effect was negative for wage equity (see Figure 2).

The results of the models for the second behavioral commitment dimension, responsibility to the union, are listed in the middle three columns in Table 4. There was a significant but weak relationship between internally focused leadership and members' responsibility to the union to begin with (.06), and the addition of the mediators reduced this coefficient to zero. The cross-level mediated effects for procedural justice and union instrumentality for non-wage outcomes were positive and significant, although the latter effect was small. The cross-level mediated effect for union instrumentality for wage outcomes was not significant. The mediated effect for wage equity was significant and negative (Figure 3 ).

The results for union participation are listed in the last three columns in Table 4 and in Figure 4. The coefficient of the relationship between the presidents' internal leadership and union participation changed from 0.10 to -0.01 when the mediators were accounted for, which suggests a possible mediation effect. However, both of these coefficients had high standard errors (0.09) and were therefore not significantly different from zero. The mediated effects were similar to the results we found for responsibility to the union except that the mediated effect of union instrumentality for non-wage outcomes was also not significant; altogether, the results of cross-level mediation provide partial support for Hypothesis 3 . The hypothesis was supported with respect to union loyalty and willingness to work for the union, but not with respect to responsibility to, and participation in, the union.

Hypothesis 4 stated that the relationship between external leadership and loyalty to the union will be mediated by perceptions of union instrumentality and wage equity. The results, listed in the last two columns in Table 3 and in Figure 5, partially supported the hypothesis. The coefficient for the direct relationship between external leadership and loyalty dropped from a significant $0.08(p<.05)$ to 0.02 ( $n s)$ after accounting for the effects of the mediators. The mediated effects for both union instrumentality variables were positive and significant, whereas the mediated effect of wage equity was negative and significant (Figure 5). The mediated effect of procedural justice was also positive.

\section{Discussion}

The purpose of this study was to discover how, and to what extent, union presidents can contribute to union members' perceptions of union instrumentality, wage equity, and beliefs about the union's use of fair decision making processes. Such perceptions and beliefs are initial steps in the formation of union commitment and participation, the usual outcome variables in psychological research on union membership. We focused the study on members' experiences 
with wages and related collective bargaining outcomes because these are of central importance to union members and often are the main reason why members belong to a union. We assumed that a relationship between leadership and union involvement would come through the leader's influence on instrumentality and justice perceptions. A secondary purpose was, therefore, to test mediation models of union commitment and participation.

We took it as a given that part of the variance in members' perceptions of union instrumentality and wage equity, union commitment, and participation would come from the union itself-that is, there would be differences between local unions that could explain members' beliefs, attitudes, and involvement levels. We argued that a significant part of those differences could be attributed to local union presidents. The data supported those hypotheses.

The results showed that there were substantial differences between local unions with respect to members' beliefs about union instrumentality for wage outcomes and wage equity, reflecting in part the reality of the unions' accomplishments at the bargaining table. There were more modest between-union differences in members' perceptions of the union's role in improving job security and working conditions and of the fairness with which wage bargaining goals were set.

Both internally and externally focused leadership explained significant amounts of variance in members' perceptions of union instrumentality and justice. In unions where members reported that their president was more engaged in making the union a viable and useful presence in the members' daily work life-solving their problems, consulting with them, and encouraging their involvement- members saw the local as more instrumental for outcome attainment, and as more inclusive, than was the case in unions with presidents who were less active internally. The positive relationships held as well where the presidents were engaged in meeting the external obligations of their leadership role-working with the employer, preparing for negotiations, monitoring the school board, building coalitions, or planning for the future. The amount of between-union variance captured by internally focused leadership was larger than the variance explained by externally focused leadership. This is not surprising given the distance in time and space between the presidents' externally focused activities and the members' personal experiences with bargaining processes and outcomes. The immediacy of what a union leader tells the members, or demonstrates directly to them, about the union's efforts, accomplishments, and future plans is likely to have a stronger effect on the members' perceptions and beliefs than will the largely unobservable outside efforts the leader expends on the members' behalf. However, some of the difference in effect sizes between internal and external leadership may be due to common method variance that will have biased the coefficients of internal leadership upward. The data on internal leadership and outcome variables came from the union members, while a different source-union staff-provided the information about external leadership.

\section{Relationships Between Union Leadership and Member Commitment and Participation}

The union-level effects on member commitment and participation were considerably smaller than the effects on members' perceptions of union instrumentality and justice. It appears that specific beliefs about, or perceptions of, the union are more sensitive to what union members experience directly than are more global attitudes and behavioral intentions. This means that there will be less between-union variance in members' actual involvement in 
the union to explain with leadership. Judging by the psychologically grounded studies on unions to date, however, it is commitment and participation that have captured researchers' interests.

We found significant positive relationships between the president's internal leadership and member loyalty to, and willingness to work for, the union, partially mediated through instrumentality and procedural justice. We had not expected to see full mediation because internal leadership could influence union commitment for reasons we did not include in the study, such as by fostering more ideologically based pro-union attitudes or by increasing perceptions of union support (e.g., Tetrick, Shore, McClurg, \& Vandenberg, 2007). As predicted, externally focused leadership was also positively related to union loyalty, explained fully by procedural justice and instrumentality perceptions.

The effects of wage equity did not support an economic model of social exchange. We had predicted that instrumentality and wage equity perceptions would be positively related to union loyalty. As expected, union instrumentality and union loyalty were positively correlated. Wage equity, however, was negatively related to all the outcome variables when we controlled for instrumentality and procedural justice. The mediating effects of wage equity were modest and should therefore not be overinterpreted, but they do suggest that union members who believe they are paid what they deserve see less of a need for getting involved in the union. The union is not the sole provider of distributive justice when it comes to wages and benefits, however. In this study, wage equity was also a function of school district wealth that influenced wage levels, so part of the members' beliefs that they were fairly paid could justifiably be attributed to employer munificence. Members' beliefs that the union had helped them obtain fair wages contributed positively to loyalty and willingness to work for the union, so it was not the union's role in ensuring wage equity that lowered affective and behavioral commitment.

The effects of procedural justice, on the other hand, were consistent with the predictions from group-value theory (Lind \& Tyler, 1988). Members' beliefs that their president used fair procedures to set union wage goals were strongly related to all commitment components and to participation.

Before we discuss the implications of our findings for union presidents, or local unions as institutions, it is worthwhile to examine the other factors that had an effect on union members' perceptions, attitudes, and behaviors. Both demographic and economic variables were related to the outcome variables in this study. Women were more inclined to report higher instrumentality and justice ratings than were men, and women reported more loyalty but less behavioral commitment. Union tenure was negatively related to instrumentality and wage equity perceptions but positively related to union commitment and participation. Wages had, as one would expect, positive effects on perceptions of wage equity, wage instrumentality, and procedural justice, as well as on behavioral commitment and union participation, but wages did not contribute to union loyalty.

There is little union leaders can do about the demographic composition of the membership, of course, other than being aware of the effects of demography and targeting the less committed and involved for inclusion.

The effects of school district size, a proxy for union size, and district wealth, an indicator of the employer's ability to pay, speak to the special challenges local leaders have in larger unions and in unions that bargain with wealthier employers. In larger unions, members were likely to report less procedural justice, and less willingness to work for, show responsibility 
toward, and participate in the union. These negative effects of size on member commitment were augmented by district wealth. A large union local where members can be spread over several workplaces could certainly constrain a president's ability to keep in contact with, service, and engage the members. Because it is easier for members in large unions to avoid active participation-it is more difficult to hide in smaller bargaining units-it suggests that internal leadership responsibilities should be more widely shared.

\section{Implications for Local Union Leadership}

Given the findings from prior research on union commitment, it was not surprising to see strong direct relationships between internally focused union leadership and members' perceptions of union instrumentality as well as mediating effects of the latter on union commitment. Our results suggest that union leaders would be well advised to make sure members see the connection between what the union is doing to obtain favorable outcomes for the membership and the outcomes they experience, not only through formal collective bargaining but also through less noticeable activities, such as informal negotiations with the employer and external coalition building. Most, if not all, union leaders will recognize the importance of bringing a "union utility" message to the membership, but it may not be obvious to a union president that spending more time directly engaged with the rank-and-file would be time well spent.

We suggest that the effective management of the union's internal state, or "health," goes beyond the service orientation identified in the shop stewards studies (Metochi, 2002; Nicholson et al., 1980) to include the creation and maintenance of an organization that is a constant presence or force in the members' work lives. In other words, an effective local president should make sure members are aware of the union and what it is doing for them all the time, not only during grievance hearings and contract negotiations.

The same argument holds with respect to procedural justice. The positive relationships between the members' beliefs that their leaders used fair processes and union commitment and participation testify to the importance of including members in union decision making. Giving members a voice in relevant decisions by consulting with them, and listening to them, is not the same as getting them actively involved in working for the union-the ultimate goal of increasing union commitment-but it appears to be a step on the way toward having a more active membership.

Although the relationships between external leadership and members' beliefs and attitudes were modest, it does not mean that union presidents, or other union officers, can ignore the external component of their jobs. We can say less about the possible effects of external leadership on union members on the basis of our data, but that in no way diminishes the importance of external leadership to the union and its members.

Our leadership measures were based on an analysis of the union president's role and were intended to capture different leader activities both within and outside the local. However, neither the members nor the field staff ratings provided a clearly articulated picture of different dimensions of either internal or external leadership. Scale items were highly intercorrelatedthe president who was perceived as active in one area was also seen as active in the other areas. Internal and external leadership were also positively correlated, which suggests that the president who worked to make the union an active and useful presence in the members' work life was also actively engaged in tending to the union's business on the outside. The fact that 
there was agreement about the general activity level of the presidents from independent observers who rated leader behavior from different vantage points suggests there may be an overall "union leader engagement" effect that includes most facets of the union president's job, certainly all the ones we measured.

This was a study of union presidents. A local union president, or any other chief officer, is not alone in running the union. In some locals, the senior officer may not have much of a staff or hard working individuals in other leadership roles, but there will nevertheless be additional actors in union positions. We justified our research focus by arguing that a significant part of a union effect on members' beliefs and attitudes would be due to the president. The focus on the senior, or central, officer very likely underestimated the effects of total union leadership. A more complete study of union leadership effects might include a larger set of actors and an expanded model of the areas they serve. It would also be useful to have a broader analysis of different union leaders' engagement in, and effects of, both servicing and internal organizing activities than we were able to provide in this study.

By testing hypotheses about the psychological processes that explained the relationship between union leaders' behavior and members' attitudes toward, and involvement in, their union, we narrowed the study of the union president's role to the influence component of leadership. Occupying a leadership position in any organization requires more than exerting influence, however. As general leadership theory makes clear (e.g., Yukl, 2002), the road to leadership effectiveness includes administrative and managerial tasks as well. A more complete study of local union leadership, or even of union presidents, would go beyond our definitions of internal and external leadership to include an examination of how the leader manages, or administers, the local, including the development and maintenance of an effective leadership structure.

\section{Methodological Concerns in Studies on Unions}

This was a cross-sectional study, and if it had included only data on leadership and union members' perceptions and attitudes, we could make an argument about a reverse attribution, in which presidents of effective local unions get the credit for the union's success at the bargaining table and descriptions of leader behavior reflect a positive halo. The only way to dispose of such an alternative hypothesis in cross-sectional research is through the use of control variables.

The demographic and economic controls used in this study have important implications for psychological research on union membership and leadership. Gender, education, and union tenure are the usual controls in studies on union commitment and participation. ${ }^{10}$ Based on our results, we recommend that wages be added to the list of standard controls in research on antecedents of union commitment because they are likely to create a halo effect (negative or positive), influencing ratings of leader behaviors or characteristics that are unrelated to wage bargaining.

It was also important to control for school district wealth and size. Both had direct effects on bargaining outcomes and on member perceptions, which suggests that a search for

\footnotetext{
10 In this study, education was highly correlated with salary because the latter was determined by a Seniority $\mathrm{X}$ Education grid. We therefore excluded education from the statistical models.
} 
pure union effects on members' attitudes and behaviors will be biased upward unless we control for exogenous causes of union success.

We recommend expanding research beyond single organizations. The benefit of a study with multiple data sources and a large sample of local unions is that it makes it possible to move beyond well-known and often-examined union attitude models to look at the effects of union characteristics.

Finally, we want to note that it is also important to consider contextual variables at levels above local unions and employers because these might influence the nature of the relationships between leadership and member perceptions and attitudes. For example, in states or cities with high union density, or with tight labor markets, union leaders' use of external networks and coalition building to secure wages and benefits for the members may be more effective than it might be in areas where unions are less powerful and more constrained politically. This, in turn, could mean that the relationship between a union official's external leadership efforts and members' perceptions of union instrumentality, wage equity, and commitment would be stronger in some contextual circumstances than in others.

\section{Limitations and Conclusion}

We focused the analysis of possible leadership effects on a set of instrumentality and justice perceptions related to collective bargaining outcomes-wages, fringe benefits, job security, the work environment, and job content. This decision was driven by the importance of wage bargaining to the union and its members - the "bread and butter" of union membership-but it meant that we excluded other factors that could have been significant in the models of union commitment and participation, such as pro-union attitudes. Our primary interests were the relationships between leadership and instrumentality and justice perceptions, not commitment and participation, but it would have been a more complete study of the latter two had we used an expanded model.

The usual concerns about single-source variance apply to the data from the union members. The relationships between union leadership and member perceptions could contain common method variance. On the other hand, the individual-level correlations between scale scores ranged from .00, where there were no reasons to expect relationships, to a high of .63, where there were very good reasons to expect high positive correlations (for example, between responsibility toward, and willingness to work for, the union), which tends to mitigate the concern somewhat. Having leadership data from two independent sources that produced similar results also strengthens our findings.

A common problem for all studies that use leader behavior scales is the influence of implicit leadership theories on ratings (Lord, 1985; Lord \& Maher, 1991). There are no scale construction procedures that will eliminate them, but there are steps one can take to encourage the raters' use of episodic memory (remembering) instead of semantic memory (knowing; see Martell \& Evans, 2005). One can ground measurement in specific events in specific contexts that are less influenced by the raters' general knowledge about leadership or leader traits and prototypes (Gioia \& Sims, 1985; Uleman, 1991). We designed our scale items to be specific to the local unions in this study and to cover leader behaviors that were related to union activities and member's concerns, such as talking to members about contract proposals, contract negotiations, and members' rights under the contract; talking to members about becoming active in the local union; or helping members solve conflicts with school 
administration. Some of the scale items were more general, however, such as counseling members about work related problems, and therefore more likely to access semantic memory. With respect to scale items triggering vivid memory as opposed to a general feeling (Martell \& Evans, 2005), we believe that the union context is sufficiently different from the teachers' regular work context-they are exposed to the union context less regularly than to their classrooms and school buildings and may therefore have had a better recall of what they actually experienced or observed instead of a more general impression of internal leadership. We cannot argue that our measure is free from implicit theory bias, however; we can argue only that we did our best to minimize it.

The third question one can raise is whether our results can be generalized beyond teachers' unions or associations. This study was about relationships between variables, not magnitudes. There is no obvious theoretical reason why public school teachers should respond differently to union instrumentality and justice than do members of other unions. There is also some empirical evidence that demonstrates the similarity of responses to union commitment scales between members of teachers' associations and mail carriers' unions (Bayazit et al., 2004). The external role of the president of a teachers' union local is to some extent shaped by the special political constraints on, and opportunities provided by, the public funding for education and by the nature of the teaching profession, but local union leaders will always have to respond to their specific environments regardless of their members' occupations and industry. The common denominator for all unions is the effort to improve the conditions of employment for the membership.

We think this study demonstrates the value of including union-specific institutional knowledge in research on union commitment and participation. Knowing what was of particular importance to the state and national association shaped our models with respect to the definition of union leadership and the emphasis placed on wage bargaining and justice. Both proved important as explanatory and outcome variables. We believe that conceptual and empirical work on the psychology of leadership, attitudes, and involvement in unions would benefit from increased knowledge about unions as institutions as well as increased knowledge of industrial relations theory.

\section{References}

Aryee, I. S., \& Chay, Y. W. (2001). Workplace justice, citizenship behavior, and turnover intentions in a union context: Examining the mediating role of perceived union support and union instrumentality. Journal of Applied Psychology, 86, 239-246.

Bacharach, S. B., Bamberger, P. A., \& Sonnestuhl, W. J. (2001). Mutual aid and union renewal. Ithaca, NY: Cornell University Press.

Bamberger, P. A., Kluger, A. N., \& Suchard, R. (1999). The antecedents and consequences of union commitment: A meta-analysis. Academy of Management Journal, 42(3), 304-318.

Barling, J., Fullagar, C., \& Kelloway, E. K. (1992). The union and its members: A psychological 
approach. New York: Oxford University Press.

Batstone, E., Boraston, I., \& Frenkel, S. (1977). Shop stewards in action: The organization of workplace conflict and accommodation. Oxford, United Kingdom: Basil Backwell.

Bayazit, M., Hammer, T. H., \& Wazeter, D. L. (2004). Methodological challenges in union commitment studies. Journal of Applied Psychology, 89, 738-747.

Blau, P. M. (1986). Exchange and power in social life. New Brunswick, NJ: Transaction.

Bollen, K., \& Lennox, R. (1991). Conventional wisdom on measurement: A structural equation perspective. Psychological Bulletin, 110, 305-314.

Bronfenbrenner, K, Friedman, S., Hurd, R. W., Oswald, R. A., \& Seeber, R. L. (1998). Organizing to win. New research on union strategies. Ithaca, NY: Cornell University Press.

Bryson, A., Cappellari, L., \& Lucifora, L. (2004). Does union membership really reduce job satisfaction? British Journal of Industrial Relations, 42, 439-459.

Catlett, J. L., \& Brown, E. L. (1990). Union leaders' perception of the grievance process. Labor Studies Journal, 15, 54-65.

Chang, T. F. H. (2005). Local union leaders' conception of ideology of stewards' roles. Labor Studies Journal, 30, 49-71.

Colquitt, J. A., Conlon, D. E., Wesson, M. J., Porter, C. O. L. H., \& Ng, K. Y. (2001). Justice at the millennium: A meta-analytic review of 25 years of organizational justice research. Journal of Applied Psychology, 86, 425-445.

Cropanzano, R., Rupp, D. E., Mohler, C. J., \& Schminke, M. (2001). Three roads to organizational justice. In G. R. Ferris (Ed.), Research in personnel and human resources management (Vol. 20, pp. 1-113). Greenwich, CT: JAI Press.

Deutsch, M. (1975). Equity, equality, and need: What determines which value will be used as the basis for distributive justice? Journal of Social Issues, 31, 137-149.

Dyer, N. G., Hanges, P. J., \& Hall, R. J. (2005). Applying multilevel confirmatory factor analysis techniques to the study of leadership. The Leadership Quarterly, 16, 149-167.

Eaton, A. E., Rubinstein, A., \& Kochan, T. A. (2008). Balancing acts: Dynamics of a union coalition in a labor management partnership. Industrial Relations, 47, 10-33.

Edwards, J. R., \& Bagozzi, R. P. (2000). On the nature and direction of relationships between constructs and measures. Psychological Methods, 5, 155-174. 
Fletcher, B., \& Hurd, R. W. (1998). Political will, local union transformation, and the organizing imperative. In B. Nissen (Ed.), Which direction for organized labor? (pp. 191-216). Detroit, MI: Wayne State University Press.

Folger, R. (1998). Justice as a moral virtue. In M. Schminke (Ed.), Managerial ethics: Moral management of people and processes (pp. 13-34). Mahwah, NJ: Erlbaum.

Folger, R., \& Konovsky, M. A. (1989). Effects of procedural and distributive justice on reactions to pay raise decisions. Academy of Management Journal, 32, 115-130.

Freeman, R. B., \& Medoff, J. L. (1984). What do unions do? New York: Basic Books.

Frost, A. C. (2000). Explaining variation in workplace restructuring: The role of local union capabilities. Industrial and Labor Relations Review, 53, 559-578.

Fullagar, C., Clark, P., Gallagher, D., \& Gordon, M. E. (1994). A model of the antecedents of early union commitment: The role of socialization experiences and steward characteristics. Journal of Organizational Behavior, 15, 517-533.

Fullagar, C., Gallagher, D. G., Clark, P. F., \& Carroll, A. (2004). Union commitment and participation: A 10-year longitudinal study. Journal of Applied Psychology, 89, 730-737.

Fullagar, C., McCoy, D., \& Shull, C. (1992). The socialization of union loyalty. Journal of Organizational Behavior, 13, 13-26.

Fuller, J. B., Jr., \& Hester, K. (2001). A closer look at the relationship between justice perceptions and union participation. Journal of Applied Psychology, 86, 1096-1105.

Gioia, D., A., \& Sims, H. P. (1985). On avoiding the influence of implicit leadership theories in leader behavior descriptions. Education and Psychological Measurement, 45, 217-232.

Gordon, M., \& Fryxell, G. (1993). The role of interpersonal justice in organizational grievance systems. In R. Cropanzano (Ed.), Justice in the workplace: Approaching fairness in human resource management (pp. 231-255). Hillsdale, NJ: Erlbaum.

Gordon, M. E., Philpot, J. W., Burt, R. E., Thompson, C. A., \& Spiller, W. E. (1980). Commitment to the union: Development of a measure and an examination of its correlates. Journal of Applied Psychology, 65, 479-499.

Grabelsky, J., \& Hurd, R. W. (1994). Reinventing an organizing union: Strategies for change. In Proceedings of the 46th annual meeting, Industrial Relations Research Association (pp. 95-104). Madison, WI: Industrial Relations Research Association. 
Greenberg, J. (1996). The quest for justice on the job: Essays and experiments. Thousand Oaks, CA: Sage.

Hammer, T. H., \& Avgar, A. (2005). The impact of unions on job satisfaction, organizational commitment, and turnover. Journal of Labor Research, 26(Spring), 241-266.

Hurd, R. W. (1998). Contesting the dinosaur image: The labor movement's search for a future. Labor Studies Journal, 22, 5-30.

Hurd, R. W. (2004). The rise and fall of the organizing model in the US. In M. Harcourt \& G. Wood (Eds.), Trade union and democracy: Strategies and perspectives. New York: Manchester University Press.

James, L. R., Demaree, R. G., \& Wolf, G. (1984). Estimating within-group interrater reliability with and without response bias. Journal of Applied Psychology, 69, 85-98.

Johnson, N. B., \& Jarley, P. (2004). Justice and union participation: An extension and test of mobilization theory. British Journal of Industrial Relations, 42, 543-562.

Katz, H. C., \& Darbishire, O. (2000). Converging divergences: Worldwide changes in employment systems. Ithaca, NY: ILR Press.

Kelloway, E. K., \& Barling, J. (1993). Members participation in local union activities:

measurement, prediction and replication. Journal of Applied Psychology, 78, 262-279.

Kerchner, C. T., \& Koppick, J. E. (1993). A union of professionals: Labor relations and education reform. New York: Teacher's College Press.

Kerchner, C. T., \& Mitchell, C. T. (1988). The changing idea of a teachers' union. New York: The Falmer Press.

Kochan, T. A., Katz, H., \& McKersie, R. (1986). The transformation of American industrial relations. New York: Basic Books.

Konovsky, M. A., \& Cropanzano, R. (1991). The perceived fairness of employee drug testing as a predictor of employee attitudes and job performance. Journal of Applied Psychology, 76, 698-707.

Konovsky, M. A., \& Pugh, S. D. (1994). Citizenship behavior and social exchange. Academy of Management Journal, 37, 656-669.

Kosnik, R. D., \& Brett, J. M. (1988). Perceptual patterns and inter-group conflict: A diagnosis for union-management relations (Technical Report). Evanston, IL: Kellogg School of Management, Northwestern University. 
Krull, J. L., \& MacKinnon, D. P. (1999). Multilevel mediation modeling in group based intervention studies. Evaluation Review, 33, 418-444.

Krull, J. L., \& MacKinnon, D. P. (2001). Multilevel modeling of individual and group level mediated effects. Multivariate Behavioral Research, 36, 249-277.

Leventhal, G. S. (1976). The distribution of rewards and resources in groups and organizations. In L. Berkowitz \& W. Walster (Eds.), Advances in experimental social psychology (pp. 2755). New York: Plenum Press.

Lincoln, J. L., \& Booth, J. N. (1993). Unions and work attitudes in the United States and Japan. Industrial Relations, 25, 159-187.

Lind, E. A. (2001). Thinking critically about justice judgments. Journal of Vocational Behavior, 58, 220-226.

Lind, E. A., \& Tyler, T. R. (1988). The social psychology of procedural justice. New York: Plenum Press.

Lipset, S. M., Trow, M., \& Coleman, J. (1956). Union democracy. The inside politics of the International Typographical Union. New York: The Free Press.

Lord, R. G. (1985). An information processing approach to social perceptions, leadership and behavioral measurement in organizations. In L. L.

Cummings \& B. M. Staw (Eds.), Research in organizational behavior (Vol. 7, pp. 87-128). Greenwich, CN: JAI Press.

Lord, R. G., \& Maher, K. J. (1991). Leadership and information processing: Linking perceptions and performance. Boston: Unwin Hyman.

MacCallum, R. C., \& Browne, M. W. (1993). The use of causal indicators in covariance structured models: Some practical issues. Psychological Bulletin, 114, 533-541.

Marchington, M., \& Armstrong, R. (1983). Shop steward organization and joint consultation. Personnel Review, 12(1), 24-32.

Martell, R. F., \& Evans, D. P. (2005). Source-monitoring training: Toward reducing rater expectancy effects in behavioral measurement. Journal of Applied Psychology, 90, 956963.

Martin, J. E., \& Peterson, M. M. (1987). Two-tier wage structures: Implication for equity theory. 
Academy of Management Journal, 30, 297-315.

Masterson, S. S., Lewis, K., Goldman, B. M., \& Taylor, M. S. (2000). Integrating justice and social exchange: The differing effects of fair procedures and treatment on work relationships. Academy of Management Journal, 43, 738-748.

Mathieu, J. E., \& Taylor, S. E. (2007). A framework for testing mesomediational relationships in organizational behavior. Journal of Organizational Behavior, 28, 141-172.

McShane, S. L. (1986). The multidimensionality of union participation. Journal of Occupational Psychology, 59, 177-187.

Metochi, M. (2002). The influence of leadership and member attitudes in understanding the nature of union participation. British Journal of Industrial Relations, 40, 87-111.

Nash, A. (1983). The union steward: Duties, rights, and status. Ithaca, NY: ILR Press.

Nicholson, N., Ursell, G., \& Blyton, P. (1980). The dynamics of whitecollar unionism: A study of local union participation. London: Academic Press.

Organ, D. W. (1990). The motivational basis of organizational citizenship behavior. In B. M. Staw \& L. L. Cummings (Eds.), Research in organizational behavior (Vol. 12, pp. 43-72). Greenwich, CT: JAI Press.

Raudenbush, S. W., \& Byrk, A. S. (2001). Hierarchical linear models: Applications and data analysis methods. Thousand Oaks, CA: Sage.

Rubinstein, S. A. (2001). The local union revisited: New voices from the front line. Industrial Relations, 40, 405-433.

Sayles, L. R., \& Strauss, G. (1967). The local union. New York: Harcourt, Brace \& World.

Shore, L. M., Tetrick, L. E., Sinclair, R. R., \& Newton, L. A. (1994). Validation of a measure of perceived union support. Journal of Applied Psychology, 79, 971-977.

Skarlicki, D. P., \& Latham, G. P. (1996). Increasing citizenship behavior within a labor union: A test of organizational justice theory. Journal of Applied Psychology, 81, 161-170.

Skarlicki, D. P., \& Latham, G. P. (1997). Leadership training in organizational justice to increase citizenship behavior within a labor union: A replication. Personnel Psychology, 50, 617634.

Tetrick, L. E. (1995). Developing and maintaining union commitment: A theoretical framework. Journal of Organizational Behavior, 16, 583-595. 
Tetrick, L. E., Shore, L. M., McClurg, L. N., \& Vandenberg, R. J. (2007). A model of union participation: The impact of perceived union support, union instrumentality, and union loyalty. Journal of Applied Psychology, 92, 820-828.

Thacker, J., Fields, M., \& Barklay, L. (1990). Union commitment: An examination of antecedent and outcome factors. Journal of Occupational Psychology, 63, 33-48.

Thibault, J., \& Walker, L. (1975). Procedural justice: A psychological analysis. Hillsdale, NJ: Erlbaum.

Tyler, T. R., \& Blader, S. L. (2000). Cooperation in groups: Procedural justice, social identity, and behavioral engagement. Philadelphia: Psychology Press.

Uleman, J. S. (1991). Leadership ratings: Toward focusing more on specific behaviors. Leadership Quarterly, 2, 175-187.

Urbanski, A. (1990). Restructuring schools for greater choice: The Rochester initiative. In S. B. Bacharach (Ed.), Education reform: Making sense of it all (pp. 298-308). Boston: Allyn and Bacon.

Yukl. G. (2002). Leadership in organizations (5th ed.). Upper Saddle River, NJ: Prentice Hall.

\section{Appendix}

Union Presidents Leadership Scales: Internally Focused Leadership

In this scale, respondents (union members) were asked to state how often their local association president does the following:

\section{Consulting and Encouraging Participation}

1. Involves members in the decision making process.

2. Encourages members to become active in the association.

3. Asks members what they would like to see in the local's contract proposals.

4. Solicits information from members about their needs and concerns.

Informing

5. Informs members about their rights under the contract.

6. Talks to members about the contract and about negotiations.

7. Keeps members informed about the local Association.

8. Makes sure members are educated about the local Association/SEA/NEA.* 


\section{Problem Solving}

9. Helps members solve conflicts with school administrators.

10. Counsels members about work related problems.

11. Helps to solve conflicts between members or different groups

of members.

12. Is there for me when I need him/her.

* SEA =State Education Association; NEA =National EducationAssociation 